\title{
HIV and HAART-Associated Dyslipidemia
}

\author{
Eoin R. Feeney ${ }^{1, *}$ and Patrick W. G. Mallon ${ }^{1,2}$ \\ ${ }^{I}$ HIV Molecular Research Group, School of Medicine and Medical Science, University College Dublin, Dublin, Ireland \\ ${ }^{2}$ Department of Infectious Diseases, Mater Misericordiae University Hospital, Dublin, Ireland
}

\begin{abstract}
Effective highly active antiretroviral therapy (HAART) for human immunodeficiency virus-1 (HIV) infection has led to marked improvement in life-expectancy for those infected with HIV. Despite reductions in the incidence of AIDS with effective treatment, patients continue to experience considerable morbidity and mortality from non-AIDS illness such as premature cardiovascular disease, liver failure and renal failure. These morbidities, particularly premature cardiovascular disease, are thought to be related to a combination of the effects of an ageing HIV-infected population coupled with long-term effects of HIV infection and antiretroviral therapy (ART). One of the principle drivers behind the well documented increase in the risk of cardiovascular disease in HIV-infected patients is dyslipidemia.

This review will focus on the clinical presentation of HIV and ART-associated dyslipidemia, what is known of its pathophysiology, including associations with use of specific antiretroviral medications, and suggest screening and management strategies.
\end{abstract}

Keywords: HIV, HAART, dyslipidemia, cholesterol, triglycerides, lipids.

\section{INTRODUCTION}

The introduction of effective highly active antiretroviral therapy (HAART) in the mid-1990s led to a marked reduction in morbidity and mortality from human immunodeficiency virus (HIV) infection [1, 2]. Increasing lifeexpectancy [3], an aging population [4], and high rates of smoking [5] have led to concerns over the cardiovascular health of HIV-infected individuals in the long term. Metabolic effects of HIV infection such as hypertriglyceridemia are long recognised [6], and side effects of HAART such as dyslipidemia and insulin resistance were described very soon after its introduction [7]. Initial concerns of increased rates of myocardial infarction arising as a result of dyslipidaemia in HIV-infected patients on antiretrovirals (ARV) $[8,9,10]$ have been confirmed by studies such as the D:A:D study, a large, prospective, multi-cohort study that showed associations between exposure to antiretroviral therapy and an increased risk of myocardial infarction [11]. In multivariate analyses, for every $\mathrm{mmol} / \mathrm{L}$ increase in total cholesterol, the relative risk of myocardial infarction increased by a factor of 1.26 [12]. In another analysis from D:A:D which included stroke, acute myocardial infarction and invasive cardiovascular procedures there was a similar effect of hypercholesterolemia, with every $\mathrm{mmol} / \mathrm{L}$ increase in total cholesterol associated with a relative risk of 1.11 of the combined endpoint [13]. There are little other data on associations between lipid profiles and other markers of vascular disease such as peripheral arterial disease.

*Address correspondence to this author at the School of Medicine and Medical Science, University College Dublin, Dublin 2, Ireland;

Tel: +353 17166518 ; Fax: +353 17166335;

E-mail: eoin.feeney@ucd.ie
Additional well-established cardiovascular risk factors are more commonly found in HIV-infected individuals such as high smoking rates [5], diabetes and insulin resistance [14] and hypertension [15]. Also, although dyslipidemia is a common problem encountered in delivering care to HIVinfected individuals, it is not the only described adverse effect of antiretroviral medications on the cardiovascular system. HIV-infected individuals have increased carotid artery intermediate thickness compared to HIV-negative controls, and those on HAART have further disturbances in vascular distensibility and compliance [16]. Endothelial function is also abnormal in HIV-infected individuals compared to negative controls, with higher serum levels of markers of endothelial dysfunction such as soluble P-selectin, von Willebrand factor and others [17]. Changes in platelet reactivity among HIV-infected individuals have been reported ${ }^{1}$, and increased insulin resistance and higher prevalence of diabetes is a well described side effect of exposure to some ARV [7, 18]. All of these factors likely act in combination with dyslipidemia to increase overall cardiovascular risk for those infected with HIV.

\section{THERAPY FOR HIV INFECTION}

Conventional HAART consists of a combination of three medications drawn from three main drug classes; nucleoside reverse transcriptase inhibitors (NRTIs - nucleoside [or nucleotide] analogues which inhibit the viral reverse tran-

\footnotetext{
${ }^{1}$ Satchell C, Cotter A, O'Connor E, et al. A Case Control Assessment of Platelet Function in HIV-1+ and HIV-1- Individuals. Abstract 737, Sixteenth Conference on Retroviruses and Opportunistic Infections, Montreal, 2009.
} 
scriptase (RT) enzyme) [19], non-nucleoside reverse transcriptase inhibitors (NNRTIs - which also inhibit the RT enzyme) and protease inhibitors (PIs - which act on the HIV protease) [20]. Traditionally HAART combines two NRTIs with either a NNRTI, or a PI [21]. The decision on which dual NRTI combination or 'backbone' to use, and which agent to combine it with, is dependent on numerous factors, including CD4+ T-cell count, HIV viral load, potential toxicities, drug interactions, pill burden and viral resistance.

\section{PATTERNS OF DYSLIPIDEMIA IN HIV}

\section{HIV Infection}

Prior to the introduction of HAART, it was recognised that HIV infection itself caused dyslipidemia [6]. Declines in total cholesterol, low density lipoprotein cholesterol (LDLC) and high density lipoprotein cholesterol (HDL-C) have been shown in men who seroconverted from HIV-negative to HIV-positive [22]. HIV-infected, untreated patients (particularly those with more advanced disease) are more likely to have low total, LDL-C and HDL-C and elevated serum triglyceride (TGs) than HIV-negative controls [23, 24, 25], with lower HDL-C concentrations associated with higher circulating HIV RNA levels and longer duration of HIV infection [26, 27].

\section{Antiretroviral Therapies}

A summary of the overall effects of antiretrovirals on serum lipids are listed in Table 1. Effective HAART sup- presses HIV RNA to undetectable levels, allowing immune recovery, measured by increases in CD4+ T-cell counts, in the majority of patients. This is usually accompanied by some increases in total cholesterol and LDL-C [22, 28] which some have suggested may be a return to norm. However, with some PI based therapies, HDL-C levels remain low [22, 29], and hypertriglyceridemia may in fact worsen [30], giving rise to a distinctly atherogenic lipid profile [31]. In contrast, initiation of NNRTI based HAART regimens has been shown to result in increases in HDL-C of approximately $40 \%$ depending on the agent used, with increases in total cholesterol, LDL-C and triglycerides also seen, although the triglyceride increases are usually not as severe as those seen with some PIs [32].

Many ARVs have dyslipidemic properties. Use of PIs has been associated with hypertriglyceridemia and hypercholesterolemia. Ritonavir, a PI, is a potent inhibitor of the hepatic cytochrome P4503A4 enzyme [33] used at a low dose with other PIs for its ability to 'boost' the drug concentrations of the PI, resulting in increased total drug exposure and halflife, allowing for improved dosing regimens and reduced pill burden [34]. In healthy volunteer studies, even when used at a boosting dose (100mg twice daily), exposure to ritonavir increased triglycerides by $26 \%$ and LDL-C by $16 \%$ after only 2 weeks of therapy [35]. When combined with other protease inhibitors such as lopinavir, serum triglycerides increased by $83 \%$, free fatty acids by $30 \%$ and VLDL-C by $33 \%$ in HIV-negative subjects after 4 weeks exposure [36]. Similar effects have also been seen in cohorts of HIV-

Table 1. Overall Effects of Main Antiretrovirals on Lipid Profiles

\begin{tabular}{|c|c|c|c|c|}
\hline \multicolumn{5}{|c|}{ Currently Recommended First-Line Agents are in Bold } \\
\hline Antiretroviral & Total Cholesterol & LDL-C & HDL-C & Triglycerides \\
\hline \multicolumn{5}{|l|}{ PIs (boosted) } \\
\hline Lopinavir & $\uparrow \uparrow$ & $\uparrow \uparrow$ & $\leftrightarrow / \downarrow$ & $\uparrow \uparrow \uparrow$ \\
\hline Atazanavir & $\uparrow$ & $\leftrightarrow / \uparrow$ & $\leftrightarrow / \downarrow$ & $\leftrightarrow$ \\
\hline Fosamprenavir & $\uparrow$ & $\uparrow$ & $\leftrightarrow / \downarrow$ & $\uparrow \uparrow$ \\
\hline Saquinavir & $\uparrow \uparrow$ & $\uparrow \uparrow$ & $\leftrightarrow / \downarrow$ & $\uparrow$ \\
\hline Darunavir & $\uparrow$ & $\uparrow$ & $\leftrightarrow / \downarrow$ & $\uparrow$ \\
\hline Tipranavir & $\uparrow \uparrow$ & $\uparrow \uparrow$ & $\leftrightarrow / \downarrow$ & $\uparrow \uparrow \uparrow$ \\
\hline \multicolumn{5}{|l|}{$\underline{\text { NNRTIs }}$} \\
\hline Efavirenz & $\uparrow$ & $\uparrow$ & $\uparrow$ & $\uparrow$ \\
\hline Nevirapine & $\uparrow$ & $\uparrow$ & $\uparrow \uparrow$ & $\leftrightarrow / \uparrow$ \\
\hline$\underline{\text { NRTIs }}$ & & & & $\leftrightarrow / \uparrow$ \\
\hline Tenofovir & $\leftrightarrow / \uparrow$ & $\leftrightarrow / \uparrow$ & $\leftrightarrow / \uparrow$ & \\
\hline Abacavir & $\leftrightarrow / \uparrow$ & $\uparrow$ & $\uparrow$ & $\uparrow$ \\
\hline Lamivudine & $\leftrightarrow$ & $\leftrightarrow$ & $\leftrightarrow$ & $\leftrightarrow$ \\
\hline Zidovudine & $\uparrow$ & $\uparrow$ & $\uparrow$ & $\uparrow \uparrow$ \\
\hline Stavudine & $\uparrow \uparrow$ & $\uparrow \uparrow$ & $\uparrow$ & $\uparrow \uparrow$ \\
\hline \multicolumn{5}{|l|}{ CCR5 Inhibitors } \\
\hline Maraviroc & $\leftrightarrow$ & $\leftrightarrow$ & $\leftrightarrow / \uparrow$ & $\leftrightarrow$ \\
\hline \multicolumn{5}{|l|}{ Integrase Inhibitors } \\
\hline Raltegravir & $\leftrightarrow / \uparrow$ & $\leftrightarrow / \uparrow$ & $\leftrightarrow / \uparrow$ & $\leftrightarrow$ \\
\hline
\end{tabular}


infected patients treated with PIs, including newer drugs such as tipranavir [29, 37, 38]. Induction of dyslipidaemia does not occur with all PIs however. Atazanavir is an azapeptide PI with relatively few effects on serum lipids [39], while other newer PIs such as darunavir have also been shown to induce less dyslipidaemia [40].

Although NNRTIs induce less dyslipidemia than PIs it does appear that efavirenz, one of two commonly prescribed NNRTIs, has a deleterious effect on lipids when compared to the other commonly used NNRTI, nevirapine. The $2 \mathrm{NN}$ study compared HAART comprising efavirenz, nevirapine or both in combination with 2 NRTI (stavudine and lamivudine) and demonstrated greater increases in triglycerides in the efavirenz arm compared to the nevirapine arm $(49 \%$ versus $20 \%$ at 48 weeks) [41]. In addition, the AIDS Clinical Trials Group (ACTG) 5142 trial, comparing therapy with lopinavir (PI) or efavirenz (NNRTI) or both with 2 NRTI, demonstrated significant increases in serum triglycerides and total cholesterol in both arms. The combination of lopinavir and efavirenz led to greater increases in serum triglycerides, non-HDL-C, and HDL-C than with either agent alone. Between lopinavir and efavirenz there was no significant difference in cholesterol levels, and only triglycerides were significantly higher in the lopinavir arm [32]. In the Swiss HIV Cohort, triglycerides tended to decrease in those treated with nevirapine but increase with efavirenz [42]. Overall, these data point to significant potential for efavirenz-induced dyslipidaemia, with increases in total cholesterol similar to some PI, but triglyceride increases that are less than observed with use of some PI.

Use of NRTI is not free of dyslipidaemia. Use of the NRTI stavudine has been associated with a worse lipid profile than the nucleotide reverse transcriptase inhibitor (NtRTI) tenofovir, with significantly larger increases in total cholesterol, LDL-C and triglycerides [43]. Similar effects were seen when tenofovir was compared to zidovudine, with significantly smaller increases in total cholesterol and LDLC observed with tenofovir use [44]. It is for reasons of toxicities such as these that tenofovir and abacavir are now the preferred first line NRTIs compared to zidovudine or stavudine [21]. Recent data from the ACTG 5202 study in which abacavir-containing HAART was compared to tenofovir-containing HAART suggested that abacavir use was associated with significantly greater increases in median triglycerides $(25 \mathrm{mg} / \mathrm{dl}$ vs $3 \mathrm{mg} / \mathrm{dl})$ and total cholesterol $(34 \mathrm{mg} / \mathrm{dl}$ vs $26 \mathrm{mg} / \mathrm{dl})$ than tenofovir at 48 weeks $^{2}$. Similar results were observed in the HEAT study, which also compared abacavir and tenofovir-containing HAART in treatment-naïve patients; those on abacavir had greater increases in serum triglycerides $(64 \mathrm{mg} / \mathrm{dl}$ vs $38 \mathrm{mg} / \mathrm{dl})$ and total cholesterol (32 mg/dl vs $23 \mathrm{mg} / \mathrm{dl})$ at 48 weeks $^{3}$, though the difference between arms was less at 96 weeks [45].

\footnotetext{
${ }^{2}$ Sax P, Tierney C, Collier AC, et al. ACTG 5202: shorter time to virologic failure (VF) with abacavir/lamivudine (ABC/3TC) than tenofovir/emtricitabine (TDF/FTC) as part of combination therapy in treatment-naïve subjects with screening HIV RNA $>100,000$ c/mL. Abstract THAB0303, XVII International AIDS Conference, Mexico City, 2008. ${ }^{3}$ Smith K, Fine D, Patel P, et al. Efficacy and Safety of Abacavir/Lamivudine Compared to Tenofovir/Emtricitabine in Combination with Once-daily Lopinavir/Ritonavir through 48 Weeks in the HEAT Study. Abstract 774, Fifteenth Conference on Retroviruses and Opportunistic Infections, Boston, 2008.
}

Although these data point to dyslipidaemia induced by ARV from all of the three commonly used drug classes, not all patients respond similarly to antiretroviral regimens (ARV). Cohorts of treatment experienced patients tend to have had more exposure to various classes of ARVs and have greater adverse effects compared to treatment naïve patients. For example, in the ARTEMIS trial, treatment naive patients started on darunavir at 96 weeks had relatively small (12-15\%) increases in total cholesterol, LDL-C and triglycerides [40]. Contrast this to the POWER studies, which used darunavir in heavily pretreated patients, where $15 \%$ of patients had TG levels of greater than $8.4 \mathrm{mmol} / \mathrm{L}$ (744mg/dL) [46].

\section{Metabolic Syndrome and HIV-Associated Lipodystrophy}

A possible explanation for the differences in dyslipidaemia upon HAART initiation observed in antiretroviral naïve versus heavily pre-treated HIV-infected patients is the changes in lipid metabolism induced by medium to long term exposure to antiretroviral therapy. While direct dyslipidemia induced by protease inhibitors can develop rapidly, other more chronic metabolic changes affecting lipid metabolism can occur with HAART. Shortly after the introduction of combination antiretroviral therapy, a syndrome of subcutaneous lipoatrophy, central adiposity, dyslipidemia, and insulin resistance, termed HIV-associated lipodystrophy (HIVLD) was noted [7]. This was initially associated with PI exposure [7], but subsequently exposure to NRTIs [47], particularly thymidine analogue NRTIs (tNRTIs) such as stavudine [48] and zidovudine [49] were also recognised as being central to the development of this syndrome. Compared to HIV-infected controls without lipodystrophy, individuals with HIVLD tend to have higher total cholesterol, total cholesterol:HDL ratios, LDL-C and triglyceride levels $[50,51]$.

In addition to HIVLD, in the general population there is concern about the increasing prevalence of the metabolic syndrome among HIV infected individuals. The pattern of abdominal obesity, low HDL-C, high triglycerides, and insulin resistance, all seen in HIVLD, are also components of the metabolic syndrome [52]. The prevalence of the metabolic syndrome in HIV-infected populations has been reported at $4.4 \%$ at enrolment in the D:A:D cohort [53], 17-25\% in other studies, and as with the general population, prevalence increases with age and BMI $[54,55,56]$. However, the most common features present in HIV-infected individuals are hypertriglyceridemia and low HDL-C [53, 54] and studies that have matched patients for age and BMI have estimated the prevalence of the metabolic syndrome to be similar among HIV-infected and HIV negative individuals [54, 55].

\section{PATHOPHYSIOLOGY OF DYSLIPIDEMIA IN HIV}

\section{HIV Infection}

Hypertriglyceridemia in untreated HIV-infected patients may be a response to a systemic inflammatory response against persistent viral infection. TG concentrations, and TG clearance time in untreated HIV-infected patients have been shown to correlate with serum interferon-alpha (IFN- $\alpha$ ) [23], which is overproduced in HIV infection [57]. In these untreated patients the activity of lipoprotein lipase (LPL) and hepatic lipase, which are both involved in TG clearance from 
the circulation, are decreased compared to controls. Treatment of hepatocytes in vitro with IFN- $\alpha$ (and other cytokines such as Il-1) causes increases in lipogenesis [58], and hepatic lipogenesis in vivo is higher in $\mathrm{HIV}$-infected individuals [59]. In hepatitis $\mathrm{C}$ virus (HCV) infected individuals receiving IFN- $\alpha$ therapy hypertriglyceridemia combined with low HDL-C levels have also been reported [60, 61], with levels returning to normal upon cessation of IFN- $\alpha$ therapy.

The activity of cholesterol ester transfer protein (CETP), which transfers cholesterol esters from HDL-C to apolipoprotein-B containing proteins [62], is elevated in HIV infection, and its activity correlates inversely with serum HDL concentrations [63]. This may help explain why HDL-C levels are lower in HIV infection. Although the reason for elevated CETP activity is still to be determined, CETP functions more efficiently in the setting of high TG levels [64], and this could help explain the increased activity in HIVinfected patients.

\section{Antiretroviral Therapies}

\section{Direct Effect}

PIs affect different tissues to cause dyslipidemia. In the liver of mice exposed to PI, excess fatty acid synthesis and hepatic steatosis occur after ritonavir exposure, which is associated with intra-nuclear accumulation of sterol response element binding proteins (SREBP), a nuclear transcription factor important for regulation of expression of many lipid metabolism genes $[65,66]$. This effect has been replicated in hepatocytes in vitro, with an increase in SREBP-1 nuclear localistion [67]. Also in the liver, PIs appear to inhibit the proteasomal degradation of pre-secretory apolipoprotein $\mathrm{B}$ (the protein component of LDL particles) in cultured hepatocytes [68]. Inhibition of proteosomal degradation of SREBP could also explain its accumulation in hepatic nuclei.

An interesting finding which points towards a hepatic cause of dyslipidemia is the fact that hepatitis $\mathrm{C}$ virus (HCV) co-infection appears to protect against the development of HAART-associated dyslipidemia [69-71]. This may be due to alterations in hepatocyte lipid secretion - mono-infection with HCV genotype $3 \mathrm{a}$ is associated with a lower serum cholesterol but a marked increase in hepatic steatosis [72].

The effect of PIs in adipose tissue is different to their effect in liver. In adipocytes, PIs inhibit lipolysis by impairing LPL activity, which impairs TG uptake into adipocytes, which may contribute to elevated plasma TG levels [73]. PIs also inhibit SREBP-1 nuclear localisation in adipocytes [74], which leads to decreased adipocyte differentiation and which may also inhibit the ability of adipose tissue to store lipids removed from the circulation. In adipocytes PIs have also been shown to reduce expression of peroxisome proliferatoractivated receptor gamma (PPAR $\gamma$ ) [75], an nuclear receptor important for adipocyte differentiation. As PPAR $\gamma$ is a transcriptional target of SREBP-1, impaired nuclear localisation of SREBP-1 in adipose tissue may contribute to reduced PPAR $\gamma$ activity.

\section{Indirect Effect}

At a cellular level, individuals with HIVLD have atrophic subcutaneous fat with smaller adipocytes, macrophage infiltration and evidence of adipocyte apoptosis [76]. It is known that tNRTIs can accumulate within adipocytes [77]. Adipocytes from patients exposed to tNRTIs demonstrate mitochondrial dysfunction, manifested by depletion of mitochondrial DNA (mtDNA) [76, 78] and reduced mitochondrial RNA (mtRNA) expression [79]. This is felt to be due in part to the ability of tNRTIs to inhibit DNA polymerase- $\gamma$, the enzyme responsible for replication of mtDNA [80]. Compared to protease inhibitors, which induce dyslipidemia within a short period of time, the effect of NRTIs on serum lipids takes longer. 6 weeks exposure to tNRTIs did not significantly alter lipid parameters in healthy volunteers, though a reduction in mtRNA expression were seen as early as 2 weeks, without reductions in mtDNA [81]. As with PIs, a downregulation of PPAR $\gamma$ expression in adipose tissue was also observed. The effect of this downregulation is potent as it cannot be overcome with the PPAR $\gamma$ agonist rosiglitazone in the presence of ongoing tNRTI use [79]. These molecular effects may explain how NRTIs can inhibit preadipocyte differentiation [82], reduce triglyceride accumulation [83] and increase adipocyte apoptosis [84] in vitro.

As well as their effects on lipid metabolism outlined above, PIs also affect adipose tissue. PIs can accumulate in adipocytes [77], and ritonavir, lopinavir and saquinavir inhibit adipocyte differentiation [85], an effect not seen with atazanavir, a PI associated with less dyslipidaemia [86]. Nelfinavir has also been shown to induce adipocyte apoptosis [87].

The ultimate result of abnormally functioning subcutaneous adipose tissue is reduced storage capacity for circulating lipids resulting in increased circulating free fatty acids [88], reduced adiponectin secretion [89], and lipid accumulation in non-adipose tissues such as liver (hepatic steatosis [90] and hepatic triglyceride accumulation [91]). This, combined with the effects of PIs on lipid metabolism as mentioned in the previous section, likely underlie the hypertriglyceridemia and hypercholesterolemia observed in HIVLD. Clinical studies have shown that a combination of a PI with NRTIs are a greater risk than PIs alone for the development of lipodystrophy and dyslipidemia [92].

\section{MANAGEMENT STRATEGIES}

Although dyslipidaemia in HIV-infected patients is common, not all patients with dyslipidemia require lipid lowering therapy. The goal of therapy, as in the HIV negative population, is to reduce an individual's cardiovascular risk. Therefore treatment of HIV-associated dyslipidemia should be an integral part of a general attempt to improve cardiovascular health, with advice on diet and exercise, smoking cessation, management of hypertension and diabetes where present, and the use of anti-platelet agents where warranted.

Despite this, in a recent retrospective review, HIVinfected veterans in the USA who met NCEP/ATPIII guidelines for dyslipidemia were half as likely to be receiving lipid lowering therapies as HIV-negative controls [93]. HIVinfected patients should be screening for dyslipidemia at HIV diagnosis, annually, and upon starting HAART. An individual's cardiovascular risk should be assessed by standardised scoring systems such as the Framingham or Joint British Societies score, and treatment instituted for those 
with previous cardiovascular disease or a high (>20\% in 10 year) risk of cardiovascular disease (Fig. 1).

Current European Aids Clinical Society (EACS) guidelines recommend target LDL-C levels dependent on an estimated 10 year cardiovascular risk. The Infectious Diseases Society of America guidelines use a similar estimate of risk. These are summarised in Table 2.

EACS guidelines recommend only treating severe isolated hypertriglyceridemia (TGs $>10 \mathrm{mmol} / \mathrm{L}$ ), or combined hyperlipidemia (LDL-C elevated and TG 2.3-10mmol/L) with lipid lowering therapy, while treating isolated hypertriglyceridemia with $\mathrm{TG}<10 \mathrm{mmol} / \mathrm{L}$ with dietary and lifestyle advice. IDSA recommend treatment of isolated TGs $>5.6 \mathrm{mmol} / \mathrm{L}(500 \mathrm{mg} / \mathrm{dL})$ or elevated LDL-C and TGs of 2.2-5.6mmol/L (200-500mg/dL).

The treatment options available for the management of dyslipidemia in HIV-infection are similar to those in the general population; dietary and lifestyle modification and the use of lipid lowering medications. An additional option in those on HAART is the ability to switch antiretrovirals away from those that may exacerbate the dyslipidemia. Although all these options have been studied in HIV-associated dyslipidemia, many studies are open-label, few are randomised and even fewer placebo-controlled. While many of these studies have shown beneficial effects of switching HAART components or lipid lowering therapy on dyslipidemia, there are no data available on the impact of these effects on cardiovascular disease endpoint and any perceived benefit is derived from corresponding beneficial effects on CVD of lipid lowering in the general population.

\section{Dietary / Lifestyle Modification}

As in the management of dyslipidemia in HIV-negative subjects, counselling on 'therapeutic lifestyle changes' such as reducing fat and cholesterol intake, increasing physical activity, weight reduction and adjusting diet to reduce LDL$\mathrm{C}$ are also important components of managing HIVassociated dyslipidemia [94], although the data on a beneficial result are inconsistent. Despite similar caloric intake,

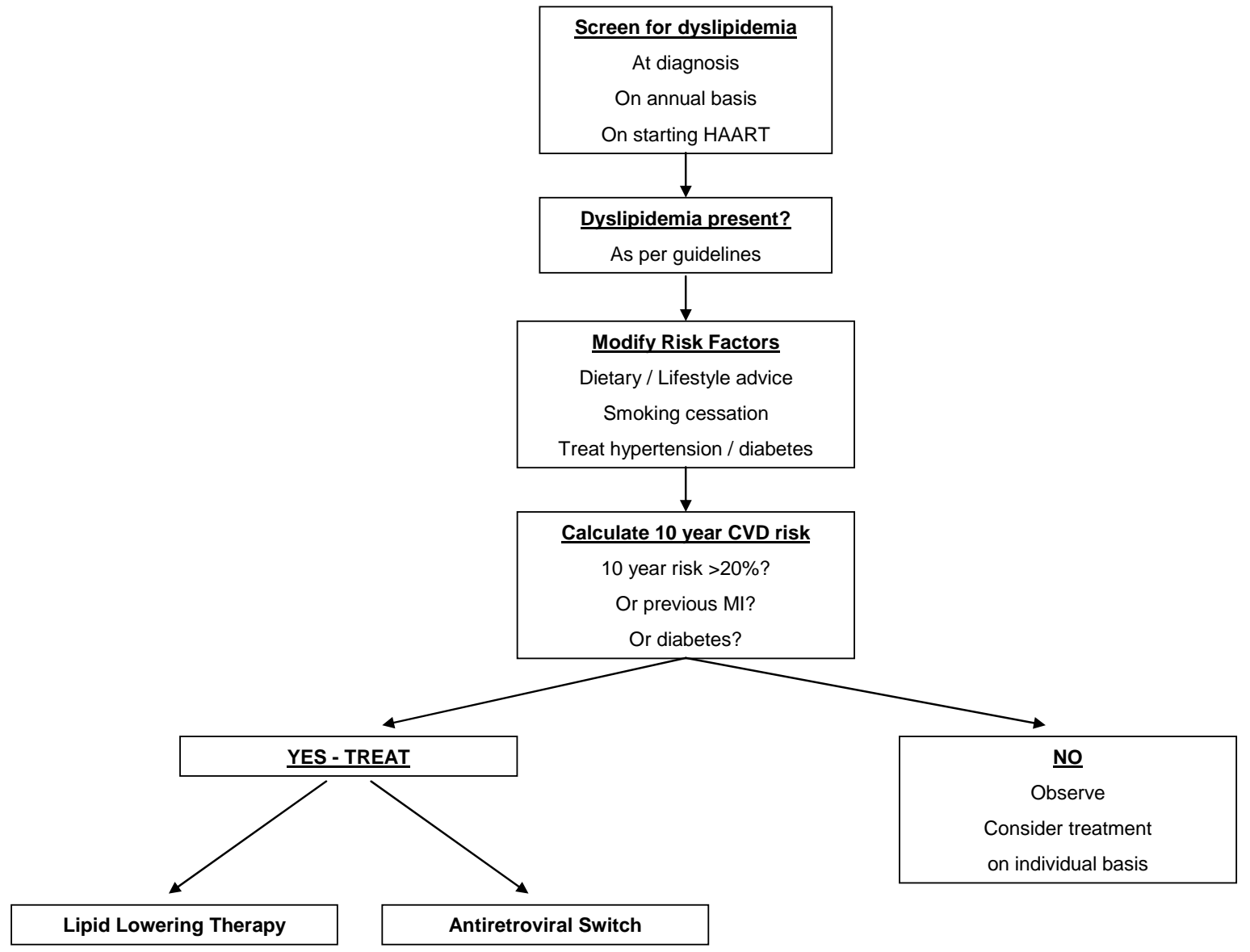

Fig. (1). Screening and treatment algorithm.

Table 2. LDL-C Treatment Goal Recommendations

\begin{tabular}{|c|c|c|c|}
\hline Recommending Group & Risk $<\mathbf{1 0 \%}$ & Risk 10-20\% & Risk >20\% Previous CV Disease Diabetes \\
\hline \hline EACS & $<5.0 \mathrm{mmol} / \mathrm{L}(<190 \mathrm{mg} / \mathrm{dL})$ & $<4.0 \mathrm{mmol} / \mathrm{L}(<155 \mathrm{mg} / \mathrm{dL})$ & $<3.0 \mathrm{mmol} / \mathrm{L}(<115 \mathrm{mg} / \mathrm{dL})$ \\
\hline IDSA/ACTG & $<4.1 \mathrm{mmol} / \mathrm{L}(<160 \mathrm{mg} / \mathrm{dL})$ & $<3.3 \mathrm{mmol} / \mathrm{L}(<130 \mathrm{mg} / \mathrm{dL})$ & $<2.6 \mathrm{mmol} / \mathrm{L}(<100 \mathrm{mg} / \mathrm{dL})$ \\
\hline
\end{tabular}


HIV-infected individuals have been shown to ingest more saturated fat than HIV-negative matched controls, and dietary saturated fat intake correlates with serum triglyceride concentrations [95]. In an early study in PI-treated patients with dyslipidemia, a diet and exercise program led to an $11 \%$ reduction in total-C, and a $21 \%$ reduction in TG [96]. However, in a study examining the effect of fish oil on serum lipids in HAART treated subjects with hypertriglyceridemia, those randomised to dietary and exercise counselling alone only reduced TG levels by $6 \%$, with no change in LDL cholesterol at 16 weeks despite decreased caloric and total fat intake [97]. In another study of individuals with hypertriglyceridemia on HAART, only 4 of 49 individuals achieved normal TG levels at any stage within an 18 month period with diet and exercise alone [98]. It is therefore unlikely that lifestyle modifications alone will suffice in correcting HAART-induced dyslipidemia in the presence of ongoing exposure to the antiretrovirals precipitating the problem.

\section{Switch Strategies}

An approach available to some HAART-treated patients with dyslipidemia is to switch away from the presumed offending agent to another ARV with less propensity to induce dyslipidemia [99]. Studies examining this strategy are summarised in Table 3 . These options should only be considered when there is a viable alternate antiretroviral agent or regimen, the new regimen is likely to induce less dyslipidemia than the original and is likely to possess similar or enhanced antiretroviral potency compared to the original regimen. At all times, maintenance of an effective ARV regimen capable of durable viral suppression is of paramount importance. Switching therapy needs careful discussion with patients about potential risks and benefits of changing what may be a virologically successful ARV regimen.

\section{PI Switches}

\section{Within Class Switching}

Switching from one PI to another has the advantage of maintaining the same class of drug whilst preserving future treatment options. Atazanavir is a potent PI with once-daily dosing and relatively favourable effects on serum lipids [39], making it an attractive option to switch to from other PIs. The need to "boost" atazanavir by using boosting doses of ritonavir [100], may reduce the beneficial effects on lipids. However, even when ritonavir-boosted, atazanavir induces less dyslipidemia than other boosted PIs [101], with the possible exception of the newer agent darunavir, which appears to have similar effects on lipid parameters to atazanavir in HIV-negative individuals [102].

Many studies examining switching to atazanavir did not actively recruit patients with dyslipidemia $[103,104,105$, 106]. However there appears to be a consistent reduction in triglycerides and cholesterol among those who switched compared to those who remained on other PIs (Table 3). This appears to hold true even for those who switch to boosted atazanavir, though the margin of reduction in lipids is smaller [104]. Atazanavir can also be used 'un-boosted'. One study that examined the effect of switching to unboosted atazanavir in patients with hypercholesterolemia demonstrated reductions in triglycerides and total cholesterol without concomitant lipid-lowering therapy [107]. However only $37 \%$ of patients achieved LDL-C $\leq 130 \mathrm{mg} / \mathrm{dL}$.

\section{Switching to a Different ARV Class}

Until recently, the options for switching away from protease inhibitors had been confined to NRTI or NNRTI switches. Switching a PI to a NNRTI such as efavirenz or nevirapine makes virological sense, as the combination of 2 NRTIs and one NNRTI is a well studied and effective antiviral combination [99]. However NNRTI have a low genetic barrier to resistance, with only one mutation required to induce high level resistance, raising concerns regarding the efficacy of this approach, particularly in patients who have been previously exposed to NNRTIs. It appears that switching to nevirapine compared to efavirenz has a better effect on lipids [108, 109]. Studies have shown that switching a PI to nevirapine has a minor effect on lipids and is virologically safe $[109,110,111]$, though the magnitude of the lipidlowering effect has been shown to be inferior to lipid lowering therapy alone [109].

Switching a PI to a NRTI such as abacavir, leaving patients on a triple combination of NRTIs, while well-tolerated and beneficial from a lipid perspective, has been shown to be virologically inferior to conventional HAART comprising drugs from more than one drug class $[112,113]$ and is now not generally recommended.

\section{NRTI Switches}

As previously discussed, thymidine analogue NRTIs (tNRTIs) are associated with subcutaneous fat loss, adipose tissue dysfunction, and increases in cholesterol and triglycerides (HIV-associated lipodystrophy). Switching away from tNRTIs to other NRTIs such as abacavir and tenofovir has been investigated as a therapeutic option for HIVLD and have resulted in both increases in subcutaneous fat [114] and improvements in dyslipidemia [115].

Switching from tNRTI to tenofovir appears to have more favourable effects on lipids than switching from tNRTI to abacavir, though the overall lipid improvements are often slight $[115,116,117]$. In one comparative randomised trial, switching from stavudine to tenofovir rather than abacavir resulted in significantly greater improvements in total cholesterol (median reduction of $0.45 \mathrm{mmol} / \mathrm{L}$ ) and LDL-C (median reduction of $0.25 \mathrm{mmol} / \mathrm{L}$ ) [114]. Similarly in the BICOMBO study, in which patients were randomised to switch from any NRTI to either tenofovir or abacavir, those switching to tenofovir had lower fasting total cholesterol, LDL-C, HDL-C and triglycerides at week 48 than those switching to abacavir [118]. However the between group differences were relatively small and there was no difference in the use of lipid lowering agents at the end of the study. One study has examined dose reduction of stavudine compared to switching to tenofovir. Despite most patients having normal lipids at baseline, switching to tenofovir resulted in greater lipid improvements than stavudine dose reduction [119]. The SWEET study examined the effect of switching from zidovudine to tenofovir. Although those switching to tenofovir 
Table 3. Antiretroviral Switch Studies and Effect on Lipids

\begin{tabular}{|c|c|c|c|c|c|c|c|c|}
\hline Study & Patient Group & $N$ & $\begin{array}{l}\text { Switch } \\
\text { From }\end{array}$ & Switch to $(N)$ & Weeks & LLT* in use & Outcome & Notes \\
\hline \multicolumn{9}{|l|}{ PI Switch } \\
\hline $\begin{array}{l}\text { Sension et al. } \\
\text { [107] }\end{array}$ & $\begin{array}{l}\text { PI based HAART } \\
\text { LDL- } \\
\text { C } \geq 130 \mathrm{mg} / \mathrm{dL}\end{array}$ & 246 & PI & $\begin{array}{l}\text { ATV } \\
\text { Immediate vs } \\
\text { delayed }\end{array}$ & 48 & No & $\begin{array}{l}\downarrow 35 \% \text { TG } \\
\downarrow 18 \% \text { LDL-C } \\
37 \% \text { achieved } \\
\text { LDL-C } \leq 130 \mathrm{mg} / \mathrm{dl}\end{array}$ & $\begin{array}{l}\text { Tenofovir not used } \\
\text { Unboosted atazanavir }\end{array}$ \\
\hline $\begin{array}{l}\text { Soriano et al. } \\
{[104]} \\
\text { (SLOAT) }\end{array}$ & $\begin{array}{l}\text { LPV/r based } \\
\text { HAART }\end{array}$ & 189 & $\mathrm{LPV} / \mathrm{r}$ & $\begin{array}{l}\operatorname{ATV}(49) \text { or } \\
\operatorname{ATV} / \mathrm{r}(53) \\
\text { vs no switch (87) }\end{array}$ & 48 & $\begin{array}{l}\text { Yes } \\
\text { (More in } \\
\mathrm{LPV} / \mathrm{r} \text { arm) }\end{array}$ & $\begin{array}{l}\downarrow 9.5 \% \text { total-C }(\downarrow 0.2 \% \text { LPV/R) } \\
\downarrow 43.7 \% \text { TG }(\downarrow 3.4 \% \text { LPV/R) } \\
\text { No significant change LDL-C } \\
4 \% \text { ATV LDL-C } \geq 160 \mathrm{mg} / \mathrm{dL} \\
16 \% \text { LPV/r LDL-C } \geq 160 \mathrm{mg} / \mathrm{dL}\end{array}$ & $\begin{array}{l}\text { ATV/r if tenofovir in NRTI backbone } \\
\text { Previous PI failure permitted } \\
12 \text { virologic failures on ATV - all } \\
\text { had previously failed PI } \\
\downarrow 21.9 \% \text { TG } \\
\downarrow 6.2 \% \text { total-C ATV/r (boosted) } \\
\downarrow 48.7 \mathrm{TG}, \downarrow 12.9 \% \text { ATV (unboosted) }\end{array}$ \\
\hline $\begin{array}{l}\text { Gatell et al. } \\
{[103]} \\
\text { (SWAN) }\end{array}$ & PI-based HAART & 419 & PI & $\begin{array}{l}\operatorname{ATV}(252) \text { or } \\
\operatorname{ATV} / \mathrm{r}(26) \\
\text { or no switch }(141)\end{array}$ & 48 & Yes & $\begin{array}{l}\downarrow 33 \% \text { TG } \\
\downarrow 18 \% \text { total-C } \\
\downarrow 12 \% \text { LDL-C }\end{array}$ & $\begin{array}{l}\text { Previous PI failure not permitted } \\
\text { ATV/r if tenofovir in NRTI backbone }\end{array}$ \\
\hline $\begin{array}{l}\text { Nguyen et al. } \\
{[105]}\end{array}$ & PI-based HAART & 36 & PI & $\mathrm{ATV} / \mathrm{r}$ & 24 & Yes & $\begin{array}{l}\downarrow 23 \% \text { TG } \\
\downarrow 9 \% \text { total-C } \\
\downarrow 13 \% \text { LDL-C }\end{array}$ & $\begin{array}{l}\text { Retrospective review } \\
47 \% \text { patients met NCEP III } \\
\text { guidelines at } 6 \text { months }\end{array}$ \\
\hline $\begin{array}{l}\text { Wood et al. } \\
\text { [106] }\end{array}$ & $\mathrm{NFV} / \mathrm{d} 4 \mathrm{~T} / 3 \mathrm{TC}$ & 63 & NFV & ATV & 24 & Yes & $\begin{array}{l}\downarrow 25 \% \text { TG } \\
\downarrow 16 \% \text { total-C } \\
\downarrow 20 \% \text { LDL-C }\end{array}$ & \\
\hline \multicolumn{9}{|l|}{ NNRTI Switch } \\
\hline $\begin{array}{l}\text { Negredo et al. } \\
{[110]}\end{array}$ & PI-based HAART & 77 & PI & $\begin{array}{l}\text { NVP (26) } \\
\text { EFV (25) } \\
\text { Vs no switch (26) }\end{array}$ & 52 & Yes & $\begin{array}{l}\downarrow 21 \% \mathrm{TG}, \downarrow 10 \% \text { total-C NVP } \\
\text { group }\end{array}$ & $\begin{array}{l}\text { No significant change EFV group or } \\
\text { no switch group }\end{array}$ \\
\hline $\begin{array}{l}\text { Estrada et al. } \\
{[108]}\end{array}$ & $\begin{array}{l}\text { PI-based HAART } \\
\text { Lipodystrophy }\end{array}$ & 28 & PI & EFV & 48 & Yes & No significant change & No improvement lipodystrophy \\
\hline $\begin{array}{l}\text { Calza et al. } \\
\text { [109] }\end{array}$ & $\begin{array}{l}\text { PI-based HAART } \\
\text { TGs } \geq 200 \mathrm{mg} / \mathrm{dL} \\
\text { Total-C } \\
>250 \mathrm{mg} / \mathrm{dL}\end{array}$ & 130 & PI & $\begin{array}{l}\text { NVP (29) } \\
\text { EFV (34) } \\
\text { Vs lipid } \\
\text { lowering (67) }\end{array}$ & 52 & $\begin{array}{l}\text { No } \\
\text { (comparator) }\end{array}$ & $\begin{array}{l}\downarrow 25 \% \mathrm{TG}, \downarrow 27 \% \text { total-C NVP } \\
\text { group } \\
\downarrow 9.4 \% \mathrm{TG}, \downarrow 24 \% \text { total-C EFV } \\
\text { group }\end{array}$ & $\begin{array}{l}\text { Lipid lowering therapies } \\
\text { (statin / fibrate) better than switch }\end{array}$ \\
\hline $\begin{array}{l}\text { Martinez et al. } \\
{[112]}\end{array}$ & PI-based HAART & 460 & PI & $\begin{array}{l}\text { NVP (155) } \\
\text { EFV (156) } \\
\text { ABC (162) }\end{array}$ & 52 & Yes & $\begin{array}{l}\text { No difference in median TG } \\
\text { levels } \\
\text { Total-C lower in } \mathrm{ABC} \text { group } \\
\text { Fewer patients in } \mathrm{ABC} \text { group: } \\
\text { with } \mathrm{TG} \geq 400 \mathrm{mg} / \mathrm{dL} \\
\text { with total-C } \geq 240 \mathrm{mg} / \mathrm{dL}\end{array}$ & $\begin{array}{l}\text { Higher virologic failure } \\
\text { in abacavir group }\end{array}$ \\
\hline $\begin{array}{l}\text { Martinez et al. } \\
{[150]}\end{array}$ & $\begin{array}{l}\text { PI based HAART } \\
\text { Lipodystrophy }\end{array}$ & 20 & PI & EFV & 24 & Yes & $\begin{array}{l}\downarrow 25 \% \text { TG } \\
\text { No change total-C }\end{array}$ & No improvement lipodystrophy \\
\hline $\begin{array}{l}\text { Carr et al. } \\
{[151]}\end{array}$ & $\begin{array}{l}\text { PI-based HAART } \\
\text { Lipodystrophy }\end{array}$ & 81 & PI & $\begin{array}{l}\text { NVP+ABC (49) } \\
\text { +hydroxyurea } \\
\text { +adefovir } \\
\text { vs no switch (32) }\end{array}$ & 24 & Yes & $\begin{array}{l}\text { Switch group: } \\
\downarrow 34.6 \% \text { TG } \\
\downarrow 25 \% \text { total-C }\end{array}$ & $\begin{array}{l}\text { Significant between group difference } \\
\text { in total-C and TG } \\
37 \% \text { discontinuation rate in switch } \\
\text { group at } 24 \text { weeks }\end{array}$ \\
\hline $\begin{array}{l}\text { Petit et al. } \\
\text { [111] }\end{array}$ & PI-based HAART & 55 & PI & NVP & 24 & Yes & $\begin{array}{l}\downarrow 17.8 \% \text { TG } \\
\text { No change in total cholesterol } \\
\uparrow 16.8 \% \text { HDL-C }\end{array}$ & $\begin{array}{l}\text { Significant change in } \\
\text { TG only seen in men } \\
\text { Men had higher TG at baseline }\end{array}$ \\
\hline
\end{tabular}


Table 3. contd....

\begin{tabular}{|c|c|c|c|c|c|c|c|c|}
\hline Study & Patient Group & $N$ & $\begin{array}{l}\text { Switch } \\
\text { From }\end{array}$ & Switch to $(N)$ & Weeks & LLT* in use & Outcome & Notes \\
\hline \multicolumn{9}{|l|}{ NRTI Switch } \\
\hline $\begin{array}{l}\text { Llibre et al. } \\
{[116]}\end{array}$ & $\begin{array}{l}\text { On d4T with } \\
\text { toxicity } \\
\text { (172 with } \\
\text { dyslipidemia) }\end{array}$ & 352 & $\mathrm{~d} 4 \mathrm{~T}$ & Tenofovir & 48 & Yes & $\begin{array}{l}\text { In patients with baseline } \\
\text { dyslipidemia: } \\
\downarrow 26.9 \% \text { TG } \\
\downarrow 14.1 \% \text { total-C } \\
\downarrow 17.8 \% \text { LDL-C }\end{array}$ & $77 \%$ of patients had lipodystrophy \\
\hline $\begin{array}{l}\text { Madruga et al. } \\
{[115]}\end{array}$ & $\mathrm{d} 4 \mathrm{~T}+3 \mathrm{TC}+\mathrm{EFV}$ & 85 & $\mathrm{~d} 4 \mathrm{~T}$ & Tenofovir & 144 & Yes & $\begin{array}{l}\downarrow 78 \mathrm{mg} / \mathrm{dL} \text { TG } \\
\downarrow 22 \mathrm{mg} / \mathrm{dL} \text { total-C }\end{array}$ & \\
\hline $\begin{array}{l}\text { Ananworanich } \\
\text { et al. [117] }\end{array}$ & $\mathrm{d} 4 \mathrm{~T}+\mathrm{ddI}+\mathrm{SQV} / \mathrm{r}$ & 35 & $\begin{array}{l}\mathrm{d} 4 \mathrm{~T} \\
\mathrm{ddI}\end{array}$ & $\begin{array}{l}\text { Tenofovir } \\
+ \text { Lamivudine }\end{array}$ & 48 & Yes & $\begin{array}{l}\downarrow 17 \% \mathrm{TG} \\
\downarrow 4.5 \% \text { total-C } \\
\downarrow 6.7 \% \mathrm{LDL}-\mathrm{C}\end{array}$ & Some improvement in lipoatrophy \\
\hline $\begin{array}{l}\text { Martin et al. } \\
{[152]}\end{array}$ & $\begin{array}{l}\text { tNRTI-containing } \\
\text { HAART } \\
\text { Lipoatrophy }\end{array}$ & 85 & $\begin{array}{l}\mathrm{d} 4 \mathrm{~T} / \\
\mathrm{AZT}\end{array}$ & $\begin{array}{l}\text { Abacavir (42) } \\
\text { vs no switch }\end{array}$ & 104 & Yes & $\begin{array}{l}\text { No improvement in } \\
\text { lipid parameters }\end{array}$ & Some improvement in lipoatrophy \\
\hline $\begin{array}{l}\text { Moyle et al. } \\
{[114]}\end{array}$ & $\begin{array}{l}\text { tNRTI-containing } \\
\text { HAART } \\
\text { Lipoatrophy }\end{array}$ & 105 & $\begin{array}{l}\mathrm{d} 4 \mathrm{~T} / \\
\mathrm{AZT}\end{array}$ & $\begin{array}{l}\text { Tenofovir (52) } \\
\text { Abacavir (53) }\end{array}$ & 48 & Yes & $\begin{array}{l}\text { Tenofovir: } \\
\downarrow 8 \% \text { total-C, } \downarrow 16.5 \% \mathrm{TG}, \\
\downarrow 7.5 \% \text { LDL-C } \\
\text { Abacavir } \\
\uparrow 3.9 \% \text { total-C, } \uparrow 4.1 \% \mathrm{TG}, \uparrow 3 \% \\
\text { LDL-C }\end{array}$ & $\begin{array}{l}\text { Significant differences in total-C and } \\
\text { LDL-C between arms } \\
\text { Both arms had increase in limb fat } \\
\text { Small rises in cholesterol in both } \\
\text { arms when switching from AZT }\end{array}$ \\
\hline $\begin{array}{l}\text { Schwede et al. } \\
{[153]}\end{array}$ & $\begin{array}{l}\text { d4T containing } \\
\text { HAART }\end{array}$ & 66 & $\mathrm{~d} 4 \mathrm{~T}$ & Tenofovir & $\begin{array}{l}72 \\
(\text { mean })\end{array}$ & Yes & $\begin{array}{l}\downarrow 36 \mathrm{mg} / \mathrm{dL} \text { total-C } \\
\text { No significant } \downarrow \text { TG at } 72 \text { weeks }\end{array}$ & $\begin{array}{l}\text { Retrospective analysis } \\
\text { Initial } 84 \mathrm{mg} / \mathrm{dL} \text { decrease in TGs at } \\
12 \text { weeks }\end{array}$ \\
\hline $\begin{array}{l}\text { Milinkovic } \\
\text { et al. [119] }\end{array}$ & $\begin{array}{l}\text { d4T containing } \\
\text { HAART } \\
\text { Lipoatrophy }\end{array}$ & 58 & $\mathrm{~d} 4 \mathrm{~T}$ & $\begin{array}{l}\text { Tenofovir (17) } \\
\text { Low dose d4T (19) } \\
\text { vs continue d4T (22) }\end{array}$ & 24 & None used & $\begin{array}{l}\text { Low dose } \mathrm{d} 4 \mathrm{~T} \\
\downarrow 8 \% \text { TG } \uparrow 0.6 \% \text { total-C } \\
\text { Tenofovir } \\
\downarrow 28.7 \% \text { TG } \downarrow 15.6 \% \text { total-C }\end{array}$ & $\begin{array}{l}\text { Most patients had normal lipids at } \\
\text { baseline }\end{array}$ \\
\hline $\begin{array}{l}\text { Martinez et al. } \\
{[118]} \\
\text { (BICOMBO) }\end{array}$ & $\begin{array}{l}\text { HAART with } 2 \\
\text { NRTIs }\end{array}$ & 333 & NRTI & $\begin{array}{l}\text { Tenofovir / FTC } \\
(166) \\
\text { Abacavir / 3TC } \\
(167)\end{array}$ & 48 & Yes & $\begin{array}{l}\text { Total-C, LDL-C, HDL-C, TGs } \\
\text { lower in tenofovir arm }\end{array}$ & $\begin{array}{l}\text { Lipid lowering agent use similar in } \\
\text { both arms }\end{array}$ \\
\hline $\begin{array}{l}\text { Fisher et al. } \\
{[120]} \\
\text { (SWEET) }\end{array}$ & $\begin{array}{l}\text { AZT with } \\
3 \mathrm{TC}+\mathrm{EFV}\end{array}$ & 234 & AZT & $\begin{array}{l}\text { Tenofovir (117) } \\
\text { vs no switch (117) }\end{array}$ & 48 & Yes & $\begin{array}{l}\text { Greater decrease in total-C, TGs } \\
\text { in tenofovir arm at week } 24\end{array}$ & $\begin{array}{l}\text { No significant difference at week } 48 \\
\text { Reduction greatest in those with } \\
\text { higher levels at baseline }\end{array}$ \\
\hline
\end{tabular}

*LLT = lipid lowering therapy.

had lower total cholesterol and triglycerides at 24 weeks (with the greatest reductions occurring in those with the highest baseline values), there were no statistically significant between group differences at 48 weeks between each arm [120].

\section{Treatment Interruption}

Cessation of HAART has been proposed as a therapeutic option in dyslipidemia, and does result in improvements in TG, total-C and LDL-C even after a short period of time [121]. However, clinical studies have shown excess morbidity and mortality, including increased major cardiovascular, renal and hepatic events in those undergoing treatment interruption [122]. As a result this strategy should not be considered as therapy for dyslipidemia.

\section{Lipid Lowering Therapies}

Many lipid lowering therapies have been investigated in HIV infection (summarised in Table 4). The treatment of dyslipidemia in HIV infection is often complicated by potential drug interactions between ARV and lipid-lowering medications. In addition, other medications used in the treatment of HIV-infection such as macrolide antibiotics [123], azole antifungals [124] or the rifamycin antimycobacterials [125] may also have significant interactions with lipid-lowering agents.

\section{Fish Oils}

Fish oils, rich in omega-3 fatty acids, can help lower triglycerides and have been studied in HIV-infected patients. 
Table 4. Trials of Lipid Lowering Agents in HIV Infection

\begin{tabular}{|c|c|c|c|c|c|c|}
\hline Study & Patient Group & $N$ & Intervention $(N)$ & Followup & Outcome & Notes \\
\hline \multicolumn{7}{|l|}{ Fish Oils } \\
\hline $\begin{array}{l}\text { Wohl et al. } \\
\text { [97] }\end{array}$ & $\begin{array}{l}\text { On HAART } \\
\mathrm{TG} \geq 200 \mathrm{mg} / \mathrm{dl}\end{array}$ & 52 & $\begin{array}{l}3 \mathrm{~g} \text { fish oil / day ( } 26) \\
v s \text { diet and exercise alone }\end{array}$ & 16 & $\begin{array}{l}\downarrow 19.5 \% \mathrm{TG} \\
(\downarrow 5.7 \% \mathrm{TG} \text { in diet/ } \\
\text { exercise })\end{array}$ & $\begin{array}{l}\text { No significant difference at week } 16 \\
\text { Approximately } 20 \% \text { increase } \\
\text { LDL cholesterol both arms }\end{array}$ \\
\hline $\begin{array}{l}\text { Gerber et al. } \\
{[126]}\end{array}$ & $\begin{array}{l}\text { On HAART } \\
\text { TG } \geq 400 \mathrm{mg} / \mathrm{dl}, \text { LDL- } \\
\mathrm{C} \leq 160 \mathrm{mg} / \mathrm{dL}\end{array}$ & 100 & $\begin{array}{l}6 \mathrm{~g} \text { fish oil / day }(50) \\
v s \text { fenofibrate }\end{array}$ & 8 & $\begin{array}{l}\downarrow 46 \% \text { TG } \\
\uparrow 37 \% \text { LDL-C }\end{array}$ & $\begin{array}{l}8.5 \% \text { achieved } \mathrm{TG} \leq 200 \mathrm{mg} / \mathrm{dL} \\
\text { Addition of fenofibrate allowed } 22.1 \% \text { to achieve } \\
\mathrm{TG} \leq 200 \mathrm{mg} / \mathrm{dL} \text { at } 18 \text { weeks }\end{array}$ \\
\hline $\begin{array}{l}\text { Manfredi et al. } \\
\text { [98] }\end{array}$ & $\begin{array}{l}\text { On HAART } \\
\text { TG } 200-500 \mathrm{mg} / \mathrm{dl} \text { on } 2 \\
\text { occasions }\end{array}$ & 156 & $\begin{array}{l}2 \mathrm{~g} \text { polyunsaturated ethyl esters of } \\
\mathrm{n}-3 \text { fatty acids / day ( } 54) \\
\text { vs fibrates } v \text { s diet and exercise }\end{array}$ & 72 & $\downarrow 11.6 \% \mathrm{TG}$ & $\begin{array}{l}25.9 \% \text { achieved target } \mathrm{TG} \leq 172 \mathrm{mg} / \mathrm{dL} \text { at any stage } \\
\text { Superior to diet and exercise alone }\end{array}$ \\
\hline \multicolumn{7}{|l|}{ Fibrates } \\
\hline $\begin{array}{l}\text { Palacios et al. } \\
{[129]}\end{array}$ & $\begin{array}{l}\text { On HAART } \\
\mathrm{TG} \geq 400 \mathrm{mg} / \mathrm{dl}\end{array}$ & 20 & Fenofibrate $200 \mathrm{mg} /$ day & 24 & $\begin{array}{l}\downarrow 53.6 \% \mathrm{TG} \\
\downarrow 14.1 \% \text { total-C }\end{array}$ & $70 \%$ achieved $\mathrm{TG} \leq 400 \mathrm{mg} / \mathrm{dl}$ \\
\hline $\begin{array}{l}\text { Badiou et al. } \\
\text { [127] }\end{array}$ & $\begin{array}{l}\text { On HAART } \\
\mathrm{TG} \geq 175 \mathrm{mg} / \mathrm{dL}\end{array}$ & 36 & $\begin{array}{l}\text { Fenofibrate 200mg/day (18) } \\
\text { vs Vitamin E }\end{array}$ & 12 & $\begin{array}{l}\downarrow 40 \% \text { TG } \\
\downarrow 14 \% \text { total-C } \\
\uparrow 15 \% \text { HDL-C }\end{array}$ & \\
\hline $\begin{array}{l}\text { Aberg et al. } \\
{[131]}\end{array}$ & $\begin{array}{l}\text { On HAART } \\
\text { Combined dyslipidemia }\end{array}$ & 88 & Fenofibrate $200 \mathrm{mg} /$ day & 12 & & $1 \%$ achieved NCEP guidelines on fenofibrate alone \\
\hline $\begin{array}{l}\text { Gerber et al. } \\
{[126]}\end{array}$ & $\begin{array}{l}\text { On HAART } \\
\mathrm{TG} \geq 400 \mathrm{mg} / \mathrm{dl}, \mathrm{LDL}- \\
\mathrm{C} \leq 160 \mathrm{mg} / \mathrm{dL}\end{array}$ & 100 & $\begin{array}{l}\text { Fenofibrate } 160 \mathrm{mg} / \text { day }(50) \\
\text { vs fish oil }\end{array}$ & 8 & $\begin{array}{l}\downarrow 58 \% \text { TG } \\
\downarrow 46 \% \text { LDL-C } \\
\downarrow 10 \% \text { total-C }\end{array}$ & $\begin{array}{l}16.7 \% \text { achieved } \mathrm{TG} \leq 200 \mathrm{mg} / \mathrm{dL} \\
\text { Addition of fish oil allowed } 22.1 \% \text { to achieve } \mathrm{TG} \\
\leq 200 \mathrm{mg} / \mathrm{dL} \text { at } 18 \text { weeks }\end{array}$ \\
\hline $\begin{array}{l}\text { Manfredi } \\
\text { et al. }[98]\end{array}$ & $\begin{array}{l}\text { On HAART } \\
\text { TG } 200-500 \mathrm{mg} / \mathrm{dl} \text { on } 2 \\
\text { occasions }\end{array}$ & 156 & $\begin{array}{l}\text { Bezafibrate / Gemfibrozil / } \\
\text { Fenofibrate (53) }\end{array}$ & 72 & $\begin{array}{l}34 \% \text { achieved target } \\
\mathrm{TG} \leq 172 \mathrm{mg} / \mathrm{dL} \\
\text { at any stage }\end{array}$ & Superior to fish oil \& diet and exercise \\
\hline $\begin{array}{l}\text { Miller et al. } \\
\text { [154] }\end{array}$ & $\begin{array}{l}\text { On PI-containing HAART } \\
\mathrm{TG} \geq 263 \mathrm{mg} / \mathrm{dL}\end{array}$ & 37 & $\begin{array}{l}\text { Gemfibrozil } 600 \mathrm{mg} / \text { day }(17) \\
\text { Vs placebo }\end{array}$ & 12 & $\downarrow 100 \mathrm{mg} / \mathrm{dL}$ TG & Did not achieve significance \\
\hline $\begin{array}{l}\text { Calza et al. } \\
\text { [128] }\end{array}$ & $\begin{array}{l}\text { On PI-containing HAART } \\
\text { TG } \geq 300 \mathrm{mg} / \mathrm{dl} \\
+/ \text { - total-C } \geq 290 \mathrm{mg} / \mathrm{dl}\end{array}$ & 106 & $\begin{array}{l}\text { Bezafibrate } 400 \mathrm{mg} \text { / day (25) } \\
\text { Gemfibrozil } 600 \mathrm{mg} \text { / day (22) } \\
\text { Fenofibrate } 200 \mathrm{mg} \text { / day ( } 22) \\
\text { vs pravastatin / fluvastatin }\end{array}$ & 52 & $\begin{array}{l}\downarrow 40.7 \% \text { TG } \\
\downarrow 21.9 \% \text { total-C }\end{array}$ & Statins / fibrates achieved similar reductions \\
\hline $\begin{array}{l}\text { Calza et al. } \\
{[109]}\end{array}$ & $\begin{array}{l}\text { On PI-containing HAART } \\
\mathrm{TG} \geq 200 \mathrm{mg} / \mathrm{dl} \\
\text { Total-C } \geq 250 \mathrm{mg} / \mathrm{dl}\end{array}$ & 130 & $\begin{array}{l}\text { Bezafibrate } 400 \mathrm{mg} / \text { day }(31) \\
\text { Vs NNRTI switch } \\
\text { Vs pravastatin }\end{array}$ & 52 & $\begin{array}{l}\downarrow 46.6 \% \mathrm{TG} \\
\downarrow 37.6 \% \text { total-C }\end{array}$ & $\begin{array}{l}\text { Statins / fibrates similar efficacy } \\
\text { Statin / fibrates superior to NNRTI switch }\end{array}$ \\
\hline \multicolumn{7}{|l|}{ Statins } \\
\hline $\begin{array}{l}\text { Calza et al. } \\
{[132]}\end{array}$ & $\begin{array}{l}\text { On PI-containing HAART } \\
\text { Total-C } \geq 240 \mathrm{mg} / \mathrm{dL} \\
\text { (TG } \geq 500 \mathrm{mg} / \mathrm{dl} \text { excluded })\end{array}$ & 16 & Rosuvastatin $10 \mathrm{mg} /$ day & 24 & $\begin{array}{l}\downarrow 30.1 \% \text { TG } \\
\downarrow 21 \% \text { total-C } \\
\downarrow 22.4 \% \text { LDL-C } \\
\uparrow 28.5 \% \text { HDL-C }\end{array}$ & \\
\hline $\begin{array}{l}\text { Bonnet et al. } \\
{[136]}\end{array}$ & $\begin{array}{l}\text { On PI-containing HAART } \\
\text { Total-C } \geq 210 \mathrm{mg} / \mathrm{dL} \\
\text { LDL-C } \geq 130 \mathrm{mg} / \mathrm{dL}\end{array}$ & 21 & $\begin{array}{l}\text { Pravastatin 40mg/day (12) } \\
\text { Vs placebo }\end{array}$ & 12 & $\begin{array}{l}\text { No change in TG } \\
\downarrow 23 \% \text { total-C } \\
\downarrow 24 \% \text { LDL-C }\end{array}$ & \\
\hline $\begin{array}{l}\text { Mallon et al. } \\
\text { [134] }\end{array}$ & $\begin{array}{l}\text { On PI-containing HAART } \\
\text { Total-C } \geq 253 \mathrm{mg} / \mathrm{dL}\end{array}$ & & $\begin{array}{l}\text { Pravastatin } 40 \mathrm{mg} / \text { day }(16) \\
\text { Vs placebo }\end{array}$ & 12 & $\begin{array}{l}\text { Greater TWAUC } \\
\text { change in } \\
\text { cholesterol in } \\
\text { pravastatin arm }\end{array}$ & $\begin{array}{l}\text { No difference in time weighted-change } \\
\text { in cholesterol between arms } \\
\text { Increased limb fat in pravastatin arm }\end{array}$ \\
\hline
\end{tabular}


Table 4. contd....

\begin{tabular}{|c|c|c|c|c|c|c|}
\hline Study & Patient Group & $N$ & Intervention $(N)$ & Followup & Outcome & Notes \\
\hline \multicolumn{7}{|l|}{ Statins } \\
\hline $\begin{array}{l}\text { Calza et al. } \\
{[128]}\end{array}$ & $\begin{array}{l}\text { On PI-containing HAART } \\
\text { TG } \geq 300 \mathrm{mg} / \mathrm{dl} \\
+/ \text { - total-C } \geq 290 \mathrm{mg} / \mathrm{dl}\end{array}$ & 106 & $\begin{array}{l}\text { Pravastatin 20mg/day (19) } \\
\text { Fluvastatin 20mg/day (18) } \\
\text { Vs fibrates }\end{array}$ & 52 & $\begin{array}{l}\downarrow 36.1 \% \text { TG } \\
\downarrow 26.9 \% \text { total-C }\end{array}$ & Statins / fibrates achieved similar reductions \\
\hline $\begin{array}{l}\text { Calza et al. } \\
{[109]}\end{array}$ & $\begin{array}{l}\text { On PI-containing HAART } \\
\mathrm{TG} \geq 200 \mathrm{mg} / \mathrm{dl} \\
\text { Total-c } \geq 250 \mathrm{mg} / \mathrm{dl}\end{array}$ & 130 & $\begin{array}{l}\text { Pravastatin } 20 \mathrm{mg} / \mathrm{day}(36) \\
\text { Vs NNRTI switch } \\
\text { Vs bezafibrate }\end{array}$ & 52 & $\begin{array}{l}\downarrow 41.2 \% \text { TG } \\
\downarrow 45.8 \% \text { total-C }\end{array}$ & $\begin{array}{l}\text { Statins / fibrates similar efficacy } \\
\text { Statin / fibrates superior to NNRTI switch }\end{array}$ \\
\hline $\begin{array}{l}\text { Palacios } \\
\text { et al. }[130]\end{array}$ & $\begin{array}{l}\text { On HAART } \\
\text { Total-C } \geq 240 \mathrm{mg} / \mathrm{dl}\end{array}$ & 20 & Atorvastatin $10 \mathrm{mg} /$ day & 24 & $\begin{array}{l}\downarrow 40 \% \text { TG } \\
\downarrow 27 \% \text { total-C } \\
\downarrow 37 \% \text { LDL-C }\end{array}$ & \\
\hline $\begin{array}{l}\text { Baldini et al. } \\
\text { [133] }\end{array}$ & $\begin{array}{l}\text { On HAART } \\
\text { Hyperlipidemia }\end{array}$ & 19 & Pravastatin 20mg/day & 8 & $\begin{array}{l}\downarrow 37 \% \text { TG } \\
\downarrow 19 \% \text { total-C }\end{array}$ & \\
\hline \multicolumn{7}{|l|}{ Niacin } \\
\hline $\begin{array}{l}\text { Gerber et al. } \\
{[143]}\end{array}$ & $\begin{array}{l}\text { On HAART } \\
\mathrm{TG} \geq 200 \mathrm{mg} / \mathrm{dL} \\
+/-\mathrm{LDL} \geq 130 \mathrm{mg} / \mathrm{dL}\end{array}$ & 14 & ER-Niacin up to $2000 \mathrm{mg} /$ day & 14 & $\begin{array}{l}\downarrow 34 \% \text { TG } \\
\downarrow 14 \% \text { total-C }\end{array}$ & Concern over glucose intolerance \\
\hline $\begin{array}{l}\text { Dube et al. } \\
{[144]}\end{array}$ & $\begin{array}{l}\text { On HAART } \\
\text { TG } \geq 200 \mathrm{mg} / \mathrm{dL} \\
\text { non-HDL-C } \geq 180 \mathrm{mg} / \mathrm{dl}\end{array}$ & 33 & ER-Niacin up to $2000 \mathrm{mg} /$ day & 48 & $\begin{array}{l}\downarrow 32 \% \mathrm{TG} \\
\downarrow 3 \% \text { total-C }\end{array}$ & Transient increases in insulin resistance \\
\hline \multicolumn{7}{|l|}{ Ezetimibe } \\
\hline $\begin{array}{l}\text { Wohl et al. } \\
\text { [141] }\end{array}$ & $\begin{array}{l}\text { On HAART } \\
\text { LDL-C } \geq 75 \mathrm{mg} / \mathrm{dL}, \\
\mathrm{TG} \leq 800 \mathrm{mg} / \mathrm{dL}\end{array}$ & 48 & Ezetimibe $10 \mathrm{mg} /$ day & 6 & $\begin{array}{l}\downarrow 5.3 \% \text { total-C } \\
\text { TG unchanged }\end{array}$ & \\
\hline $\begin{array}{l}\text { Negredo } \\
\text { et al. [142] }\end{array}$ & $\begin{array}{l}\text { On / off HAART } \\
\text { LDL-C } \geq 130 \mathrm{mg} / \mathrm{dL} \\
\text { despite pravastatin } \\
20 \mathrm{mg} / \text { day }\end{array}$ & 19 & $\begin{array}{l}\text { Ezetimibe } 10 \mathrm{mg} / \text { day } \\
+ \text { Pravastatin } 20 \mathrm{mg} / \text { day }\end{array}$ & 24 & $\begin{array}{l}\text { Significant } \downarrow \text { in LDL- } \\
\text { C, total-C } \\
\text { Significant } \uparrow \text { HDL-C } \\
\text { No change TG }\end{array}$ & $61.5 \%$ achieved LDL-C $\leq 130 \mathrm{mg} / \mathrm{dl}$ \\
\hline
\end{tabular}

They are generally well tolerated and have few side-effects. Although a randomised study of $3 \mathrm{~g}$ of fish oil daily together with diet and exercise resulted in a $19.5 \%$ mean decrease in TGs at 16 weeks (though this was not statistically significant compared to diet and exercise alone), LDL-C concentrations actually increased by $22 \%$ [97]. In a further study (ACTG 5186), comparing $6 \mathrm{~g}$ of fish oil per day to fenofibrate in HIV-infected patients on HAART with isolated severe hypertriglyceridemia, those on fish oil experienced a $46 \%$ reduction in median TG at 8 weeks, but only $8.5 \%$ achieved TG levels $\leq 200 \mathrm{mg} / \mathrm{dL}$ and LDL-C concentrations increased. Combining fish oil with fenofibrate achieved normal TG levels in $22 \%$ of patients [126]. Treatment of HIV-infected patients with moderate HAART-related hypertriglyceridemia with polyunsaturated ethyl esters of n-3 fatty acids resulted in a $11.6 \%$ reduction in TG levels at 18 months, with $25.9 \%$ of patients achieving normal TG levels at some stage over the 18 months follow-up [98]. Given the rises in LDL-C observed in these studies, it is unclear if use of fish oils in this clinical setting will have an overall clinical benefit in terms of cardiovascular risk reduction.

\section{Fibrates}

Fibrates are an attractive therapeutic option in HIVinfected patients, as hypertriglyceridemia is common and fibrates lack significant pharmacologic interactions with ARV. Fibrates reduce triglycerides by approximately 40$50 \%$ in HIV-infected patients with hypertriglyceridemia [109, 127, 128, 129], with larger reductions in those with higher baseline TG levels $[126,130]$. These effects appear to be similar to the effect of statins [128] (see below) and in one study were superior to switching PI to NNRTI [109]. In studies fibrates appear to be well tolerated, with gastrointestinal upset being the most frequently reported side effect. Proportions of patients achieving target goals vary, with one study reporting $70 \%$ achieving a target $\mathrm{TG} \leq 200 \mathrm{mg} / \mathrm{dL}$, but most others report much lower proportions ranging from 1$40 \%[98,126,131]$. Despite these benefits, it is still unclear if reductions in triglyceride concentrations alone will be sufficient to significantly alter overall cardiovascular risk in HIV-infected patients.

\section{Statins}

HMG CoA reductase inhibitors, or "statins" have been shown to be an effective method of treating hypercholesterolemia in HIV-negative individuals and are also effective in HIV-infected individuals, reducing total cholesterol by approximately $30 \%$ and triglycerides by similar amounts $[128,130,132,133]$. As with use of fibrates for hypertriglyceridaemia, the percentage of patients achieving LDL- 
C targets with statin use vary, with some studies reporting $50-60 \%$ patients reaching NCEP targets $[128,130,132]$, while others report far lower percentages $[131,134]$. Interactions between statins and antiretrovirals (ARVs) are very common. PIs inhibit the CYP3A4 metabolism of statins, and increase overall exposure to statins, in the case of simvastatin by over $3000 \%$ [135]. This has led to concerns regarding the potential for statin toxicity with PI use and for this reason simvastatin is contraindicated with concurrent PI use. However atorvastatin (at $10-80 \mathrm{mg} \mathrm{qd}$ ) and pravastatin (at 20$80 \mathrm{mg} \mathrm{qd}$ ) are less affected by this interaction and have been extensively studied with PIs $[109,128,130,136]$. Conversely, the NNRTI efavirenz induces hepatic metabolism of statins, leading to a marked reduction in the AUC for simvastatin, pravastatin and atorvastatin [137]. The newer statin rosuvastatin is only marginally metabolised by the CYP3A4 system, with most of the drug being excreted unchanged, and has been used to treat dyslipidaemia in HIV-infected patients [132]. Despite this, both lopinavir/ritonavir $[138,139]$ and atazanavir/ritonavir [140] increase both the $\mathrm{C}_{\max }$ and AUC of rosuvastatin. This may be due to blockage of the OATP-1B1 membrane transporter for rosuvastatin, of which ritonavir is a known inhibitor [138]. This transporter is involved in the hepatic uptake of rosuvastatin, therefore ritonavir inhibition may reduce the effect of rosuvastatin on lowering cholesterol despite inducing higher circulating concentrations of the drug [124].

\section{Ezetimibe}

Ezetimibe, which blocks cholesterol absorption in the intestine and is metabolised independent of the CYP3A4 pathway, appears to have minor effects in HAART-induced dyslipidemia as monotherapy [141]. However when added to pravastatin it allowed $62 \%$ of patients with hyperlipidemia to achieve a target LDL-C concentration of $\leq 130 \mathrm{mg} / \mathrm{dl}$ [142]. Its effects seem confined to LDL-C reduction as effects on triglycerides in HAART-induced dyslipidemia appear minor $[141,142]$.

\section{Niacin}

Niacin has been investigated in two small studies, and appears to be well-tolerated, reducing TG levels by approximately $30 \%$ with a smaller effect on total cholesterol $[143,144]$. A concern is the increase in insulin resistance seen in both studies. Given the concern over insulin resistance and diabetes in HIVLD the role for routine use of niacin in this setting is unclear.

\section{Combination Therapies}

There are few data reporting the efficacy or safety of combination therapies in HIV-infected individuals. One open label study allowed the addition of pravastatin or fenofibrate to those who had failed to reach NCEP guidelines on either agent as monotherapy for 12 weeks [131]. Combination therapy was well tolerated and led to reductions in TG levels particularly, but only allowed $4 \%$ of patients to achieve combined NCEP guidelines. The increased risk of rhabdomyolysis in HIV-negative individuals from the combination of statins and fibrates [124] would advise their concurrent use in HIV positive patients only be undertaken with strict caution.

\section{CONCLUSION / FUTURE DIRECTIONS}

As the ongoing roll-out of antiretroviral treatment programs in resource poor settings is continuing, use of older medications such as tNRTIs is common [145]. As a result dyslipidemia and lipodystrophy will continue to be major issues for many HAART treated patients for years to come [146]. The recent introduction of new medications with more lipid friendly profiles within existing classes such as darunavir (PI) [46], and etravirine (NNRTI) [147] will broaden the options available to clinicians. In addition, entirely new classes of drugs, such as integrase inhibitors (raltegravir) [148] and CCR5 inhibitors (maraviroc) [149] should allow more options both for antiretroviral-naïve patients starting therapy and those needing to switch therapies to avoid dyslipidaemia. Furthermore, the development of newer, selective boosting agents to replace ritonavir that lack dyslipidaemia is continuing ${ }^{4}$. Such advances could reduce the requirement for ritonavir as a boosting agent, further reducing the potential for ARV to induce dyslipidemia. Despite early data showing much less effects on lipids with these new agents, long term safety data is required and clinicians will need to remain vigilant for treatment-related toxicities as HIV-infected individuals continue to live longer and healthier lives.

\section{FUNDING}

Eoin Feeney is supported through the Clinician Scientist Fellowship Programme by Molecular Medicine Ireland. The HIV Molecular Research Group is funded through a grant by Science Foundation Ireland (09/RFP/BMT2461).

\section{REFERENCES}

[1] Bhaskaran K, Hamouda O, Sannes M, et al. Changes in the risk of death after HIV seroconversion compared with mortality in the general population. JAMA 2008; 300: 51-9.

[2] Palella FJ, Jr., Delaney KM, Moorman AC, et al. Declining morbidity and mortality among patients with advanced human immunodeficiency virus infection. HIV Outpatient Study Investigators. N Engl J Med 1998; 338: 853-60.

[3] Lohse N, Hansen AB, Pedersen G, et al. Survival of persons with and without HIV infection in Denmark, 1995-2005. Ann Intern Med 2007; 146: 87-95.

[4] Mack KA, Ory MG. AIDS and older Americans at the end of the Twentieth Century. Journal of acquired immune deficiency syndromes (1999). 2003; 33 Suppl 2: S68-75.

[5] Mamary EM, Bahrs D, Martinez S. Cigarette smoking and the desire to quit among individuals living with HIV. AIDS Patient Care STDS 2002; 16: 39-42.

[6] Grunfeld C, Kotler DP, Hamadeh R, et al. Hypertriglyceridemia in the acquired immunodeficiency syndrome. Am J Med 1989; 86: 27-31.

[7] Carr A, Samaras K, Burton S, et al. A syndrome of peripheral lipodystrophy, hyperlipidaemia and insulin resistance in patients receiving HIV protease inhibitors. AIDS 1998; 12: F51-8.

[8] Passalaris JD, Sepkowitz KA, Glesby MJ. Coronary artery disease and human immunodeficiency virus infection. Clin Infect Dis 2000; 31: 787-97.

[9] Holmberg SD, Moorman AC, Williamson JM, et al. Protease inhibitors and cardiovascular outcomes in patients with HIV-1. Lancet 2002; 360: 1747-8.

${ }^{4}$ Mathias A, Lee M, Callebaut C, et al. GS-9350 : A Pharmaco-enhancer without AntiHIV activity. Abstract 40, Sixteenth Conference on Retroviruses and Opportunistic Infections, Montreal, 2009. 
[10] Currier JS, Taylor A, Boyd F, et al. Coronary heart disease in HIVinfected individuals. J Acquir Immune Defic Syndr 2003; 33: 50612.

[11] Friis-Moller N, Sabin CA, Weber R, et al. Combination antiretroviral therapy and the risk of myocardial infarction. $\mathrm{N}$ Engl J Med 2003; 349: 1993-2003.

[12] Friis-Moller N, Reiss P, Sabin CA, et al. Class of antiretroviral drugs and the risk of myocardial infarction. N Engl J Med 2007; 356: 1723-35.

[13] d'Arminio A, Sabin CA, Phillips AN, et al. Cardio- and cerebrovascular events in HIV-infected persons. AIDS 2004; 18 : 1811-7.

[14] Brown TT, Cole SR, Li X, et al. Antiretroviral therapy and the prevalence and incidence of diabetes mellitus in the multicenter AIDS cohort study. Arch Intern Med 2005; 165: 1179-84.

[15] Hadigan C, Meigs JB, Corcoran C, et al. Metabolic abnormalities and cardiovascular disease risk factors in adults with human immunodeficiency virus infection and lipodystrophy. Clin Infect Dis $2001 ; 32$ : 130-9.

[16] van Vonderen MG, van Agtmael MA, Hassink EA, et al. Zidovudine/lamivudine for HIV-1 infection contributes to limb fat loss. PLoS One. 2009; 4: e5647.

[17] Francisci D, Giannini S, Baldelli F, et al. HIV type 1 infection, and not short-term HAART, induces endothelial dysfunction. AIDS 2009; 23: 589-96.

[18] Walli R, Herfort O, Michl GM, et al. Treatment with protease inhibitors associated with peripheral insulin resistance and impaired oral glucose tolerance in HIV-1-infected patients. AIDS 1998; 12: F167-73.

[19] Sarafianos SG, Marchand B, Das K, et al. Structure and function of HIV-1 reverse transcriptase: molecular mechanisms of polymerization and inhibition. J Mol Biol 2009; 385: 693-713.

[20] Danner SA, Carr A, Leonard JM, et al. A short-term study of the safety, pharmacokinetics, and efficacy of ritonavir, an inhibitor of HIV-1 protease. European-Australian Collaborative Ritonavir Study Group. N Engl J Med 1995; 333: 1528-33.

[21] Hammer SM, Eron JJ, Jr., Reiss P, et al. Antiretroviral treatment of adult HIV infection: 2008 recommendations of the International AIDS Society-USA panel. JAMA 2008; 300: 555-70.

[22] Riddler SA, Smit E, Cole SR, et al. Impact of HIV infection and HAART on serum lipids in men. JAMA 2003; 289: 2978-82.

[23] Grunfeld C, Pang M, Doerrler W, et al. Lipids, lipoproteins, triglyceride clearance, and cytokines in human immunodeficiency virus infection and the acquired immunodeficiency syndrome. $\mathbf{J}$ Clin Endocrinol Metab 1992; 74: 1045-52.

[24] Shor-Posner G, Basit A, Lu Y, et al. Hypocholesterolemia is associated with immune dysfunction in early human immunodeficiency virus-1 infection. Am J Med 1993; 94: 515-9.

[25] Anastos K, Lu D, Shi Q, et al. Association of serum lipid levels with HIV serostatus, specific antiretroviral agents, and treatment regimens. J Acquir Immune Defic Syndr 2007; 45: 34-42.

[26] El-Sadr WM, Mullin CM, Carr A, et al. Effects of HIV disease on lipid, glucose and insulin levels: results from a large antiretroviralnaive cohort. HIV Med 2005; 6: 114-21.

[27] Rose H, Woolley I, Hoy J, et al. HIV infection and high-density lipoprotein: the effect of the disease vs the effect of treatment. Metabolism 2006; 55: 90-5.

[28] Berthold HK, Parhofer KG, Ritter MM, et al. Influence of protease inhibitor therapy on lipoprotein metabolism. J Intern Med 1999; 246: 567-75.

[29] Periard D, Telenti A, Sudre P, et al. Atherogenic dyslipidemia in HIV-infected individuals treated with protease inhibitors. The Swiss HIV Cohort Study. Circulation 1999; 100: 700-5.

[30] Mulligan K, Grunfeld C, Tai VW, et al. Hyperlipidemia and insulin resistance are induced by protease inhibitors independent of changes in body composition in patients with HIV infection. J Acquir Immune Defic Syndr 2000; 23: 35-43.

[31] Mercie P, Tchamgoue S, Thiebaut R, et al. Atherogen lipid profile in HIV-1-infected patients with lipodystrophy syndrome. Eur J Intern Med 2000; 11: 257-63.

[32] Haubrich RH, Riddler SA, DiRienzo AG, et al. Metabolic outcomes in a randomized trial of nucleoside, nonnucleoside and protease inhibitor-sparing regimens for initial HIV treatment. AIDS 2009; 23: 1109-18.

[33] Acosta EP. Pharmacokinetic enhancement of protease inhibitors. J Acquir Immune Defic Syndr 2002; 29 Suppl 1: S11-8.
[34] Zeldin RK, Petruschke RA. Pharmacological and therapeutic properties of ritonavir-boosted protease inhibitor therapy in HIVinfected patients. J Antimicrob Chemother 2004; 53: 4-9.

[35] Shafran SD, Mashinter LD, Roberts SE. The effect of low-dose ritonavir monotherapy on fasting serum lipid concentrations. HIV Med 2005; 6: 421-5.

[36] Lee GA, Seneviratne T, Noor MA, et al. The metabolic effects of lopinavir/ritonavir in HIV-negative men. AIDS 2004; 18: 641-9.

[37] Walmsley S, Bernstein B, King M, et al. Lopinavir-ritonavir versus nelfinavir for the initial treatment of HIV infection. N Engl J Med 2002; 346: 2039-46

[38] Hicks CB, Cahn P, Cooper DA, et al. Durable efficacy of tipranavir-ritonavir in combination with an optimised background regimen of antiretroviral drugs for treatment-experienced HIV-1infected patients at 48 weeks in the Randomized Evaluation of Strategic Intervention in multi-drug reSistant patients with Tipranavir (RESIST) studies: an analysis of combined data from two randomised open-label trials. Lancet 2006; 368: 466-75.

[39] Murphy RL, Sanne I, Cahn P, et al. Dose-ranging, randomized, clinical trial of atazanavir with lamivudine and stavudine in antiretroviral-naive subjects: 48-week results. AIDS 2003; 17: 2603-14

[40] Mills AM, Nelson M, Jayaweera D, et al. Once-daily darunavir/ ritonavir vs. lopinavir/ritonavir in treatment-naive, HIV-1-infected patients: 96-week analysis. AIDS 2009; 23(13): 1679-88.

[41] van Leth F, Phanuphak P, Stroes E, et al. Nevirapine and efavirenz elicit different changes in lipid profiles in antiretroviral-therapynaive patients infected with HIV-1. PLoS Med 2004; 1: e19.

[42] Young J, Weber R, Rickenbach M, et al. Lipid profiles for antiretroviral-naive patients starting PI- and NNRTI-based therapy in the Swiss HIV cohort study. Antivir Ther 2005; 10: 585-91.

[43] Gallant JE, Staszewski S, Pozniak AL, et al. Efficacy and safety of tenofovir DF vs stavudine in combination therapy in antiretroviralnaive patients: a 3-year randomized trial. JAMA 2004; 292: 191201.

[44] Gallant JE, DeJesus E, Arribas JR, et al. Tenofovir DF, emtricitabine, and efavirenz vs. zidovudine, lamivudine, and efavirenz for HIV. N Engl J Med 2006; 354: 251-60.

[45] Smith KY, Patel P, Fine D, et al. Randomized, double-blind, placebo-matched, multicenter trial of abacavir/lamivudine or tenofovir/emtricitabine with lopinavir/ritonavir for initial HIV treatment. AIDS 2009; 23: 1547-56.

[46] Clotet B, Bellos N, Molina JM, et al. Efficacy and safety of darunavir-ritonavir at week 48 in treatment-experienced patients with HIV-1 infection in POWER 1 and 2: a pooled subgroup analysis of data from two randomised trials. Lancet 2007; 369 : 1169-78.

[47] Madge S, Kinloch-de-Loes S, Mercey D, Johnson MA, Weller IV. Lipodystrophy in patients naive to HIV protease inhibitors. AIDS 1999; 13: 735-7.

[48] Mallal SA, John M, Moore CB, James IR, McKinnon EJ. Contribution of nucleoside analogue reverse transcriptase inhibitors to subcutaneous fat wasting in patients with HIV infection. AIDS 2000; 14: 1309-16.

[49] Bogner JR, Vielhauer V, Beckmann RA, et al. Stavudine versus zidovudine and the development of lipodystrophy. $\mathbf{J}$ Acquir Immune Defic Syndr 2001; 27: 237-44.

[50] Carr A, Samaras K, Thorisdottir A, et al. Diagnosis, prediction, and natural course of HIV-1 protease-inhibitor-associated lipodystrophy, hyperlipidaemia, and diabetes mellitus: a cohort study. Lancet 1999; 353: 2093-9.

[51] Carr A, Emery S, Law M, et al. An objective case definition of lipodystrophy in HIV-infected adults: a case-control study. Lancet 2003; 361: 726-35.

[52] Grundy SM, Brewer HB, Jr., Cleeman JI, Smith SC, Jr., Lenfant C. Definition of metabolic syndrome: Report of the National Heart, Lung, and Blood Institute/American Heart Association conference on scientific issues related to definition. Circulation 2004; 109: 433-8.

[53] Worm SW, Sabin CA, Reiss P, et al. Presence of the metabolic syndrome is not a better predictor of cardiovascular disease than the sum of its components in HIV-infected individuals: data collection on adverse events of anti-HIV drugs (D: A: D) study. Diabetes Care 2009; 32: 474-80. 
[54] Jerico C, Knobel H, Montero M, et al. Metabolic syndrome among HIV-infected patients: prevalence, characteristics, and related factors. Diabetes Care 2005; 28: 132-7.

[55] Mondy K, Overton ET, Grubb J, et al. Metabolic syndrome in HIV-infected patients from an urban, midwestern US outpatient population. Clin Infect Dis 2007; 44: 726-34.

[56] Jacobson DL, Tang AM, Spiegelman D, et al. Incidence of metabolic syndrome in a cohort of HIV-infected adults and prevalence relative to the US population (National Health and Nutrition Examination Survey). J Acquir Immune Defic Syndr 2006; 43: 458-66.

[57] Grunfeld C, Kotler DP, Shigenaga JK, et al. Circulating interferonalpha levels and hypertriglyceridemia in the acquired immunodeficiency syndrome. Am J Med 1991; 90: 154-62.

[58] Grunfeld C, Dinarello CA, Feingold KR. Tumor necrosis factoralpha, interleukin-1, and interferon alpha stimulate triglyceride synthesis in HepG2 cells. Metabolism 1991; 40: 894-8.

[59] Hellerstein MK, Grunfeld $\mathrm{C}$, Wu $\mathrm{K}$, et al. Increased de novo hepatic lipogenesis in human immunodeficiency virus infection. J Clin Endocrinol Metab 1993; 76: 559-65.

[60] Fernandez-Miranda C, Castellano G, Guijarro C, et al. Lipoprotein changes in patients with chronic hepatitis $\mathrm{C}$ treated with interferonalpha. Am J Gastroenterol 1998; 93: 1901-4.

[61] Hamamoto S, Uchida Y, Wada T, et al. Changes in serum lipid concentrations in patients with chronic hepatitis $\mathrm{C}$ virus positive hepatitis responsive or non-responsive to interferon therapy. $\mathrm{J}$ Gastroenterol Hepatol 2005; 20: 204-8.

[62] Lewis GF, Rader DJ. New insights into the regulation of HDL metabolism and reverse cholesterol transport. Circ Res 2005; 96: 1221-32.

[63] Rose H, Hoy J, Woolley I, et al. HIV infection and high density lipoprotein metabolism. Atherosclerosis 2008; 199: 79-86.

[64] Guerin M, Le Goff W, Lassel TS, et al. Atherogenic role of elevated CE transfer from HDL to VLDL(1) and dense LDL in type 2 diabetes : impact of the degree of triglyceridemia. Arterioscler Thromb Vasc Biol 2001; 21: 282-8.

[65] Bengoechea-Alonso MT, Ericsson J. SREBP in signal transduction: cholesterol metabolism and beyond. Curr Opin Cell Biol 2007; 19 : 215-22.

[66] Riddle TM, Kuhel DG, Woollett LA, Fichtenbaum CJ, Hui DY. HIV protease inhibitor induces fatty acid and sterol biosynthesis in liver and adipose tissues due to the accumulation of activated sterol regulatory element-binding proteins in the nucleus. $\mathrm{J}$ Biol Chem 2001; 276: 37514-9.

[67] Zhou H, Gurley EC, Jarujaron S, et al. HIV protease inhibitors activate the unfolded protein response and disrupt lipid metabolism in primary hepatocytes. Am J Physiol Gastrointest Liver Physiol 2006; 291: G1071-80.

[68] Liang JS, Distler O, Cooper DA, et al. HIV protease inhibitors protect apolipoprotein B from degradation by the proteasome: a potential mechanism for protease inhibitor-induced hyperlipidemia. Nat Med 2001; 7: 1327-31.

[69] Di Giambenedetto S, Baldini F, Cingolani A, et al. The influence of hepatitis $\mathrm{C}$ virus coinfection on the risk of lipid abnormalities in a cohort of HIV-1-infected patients after initiation of highly active antiretroviral therapy. J Acquir Immune Defic Syndr 2004; 36 : 641-2.

[70] Cooper CL, Mills E, Angel JB. Mitigation of antiretroviral-induced hyperlipidemia by hepatitis $\mathrm{C}$ virus co-infection. AIDS 2007; 21: 71-6.

[71] Floris-Moore M, Howard AA, Lo Y, et al. Increased serum lipids are associated with higher CD4 lymphocyte count in HIV-infected women. HIV Med 2006; 7: 421-30.

[72] Hofer H, Bankl HC, Wrba F, et al. Hepatocellular fat accumulation and low serum cholesterol in patients infected with HCV-3a. Am J Gastroenterol 2002; 97: 2880-5.

[73] den Boer MA, Berbee JF, Reiss P, et al. Ritonavir impairs lipoprotein lipase-mediated lipolysis and decreases uptake of fatty acids in adipose tissue. Arterioscler Thromb Vasc Biol 2006; 26: 124-9.

[74] Caron M, Auclair M, Sterlingot H, Kornprobst M, Capeau J. Some HIV protease inhibitors alter lamin $\mathrm{A} / \mathrm{C}$ maturation and stability, SREBP-1 nuclear localization and adipocyte differentiation. AIDS 2003; 17: 2437-44.

[75] Caron M, Auclair M, Vigouroux C, et al. The HIV protease inhibitor indinavir impairs sterol regulatory element-binding protein-1 intranuclear localization, inhibits preadipocyte differentiation, and induces insulin resistance. Diabetes 2001; 50: 1378-88.

[76] Nolan D, Hammond E, Martin A, et al. Mitochondrial DNA depletion and morphologic changes in adipocytes associated with nucleoside reverse transcriptase inhibitor therapy. AIDS 2003; 17 : 1329-38.

[77] Janneh O, Hoggard PG, Tjia JF, et al. Intracellular disposition and metabolic effects of zidovudine, stavudine and four protease inhibitors in cultured adipocytes. Antivir Ther 2003; 8: 417-26.

[78] Shikuma CM, Hu N, Milne C, et al. Mitochondrial DNA decrease in subcutaneous adipose tissue of HIV-infected individuals with peripheral lipoatrophy. AIDS 2001; 15: 1801-9.

[79] Mallon PW, Sedwell R, Rogers G, et al. Effect of Rosiglitazone on Peroxisome Proliferator-Activated Receptor gamma Gene Expression in Human Adipose Tissue Is Limited by Antiretroviral Drug-Induced Mitochondrial Dysfunction. J Infect Dis 2008; 198: 1794-803.

[80] Cote HC. Possible ways nucleoside analogues can affect mitochondrial DNA content and gene expression during HIV therapy. Antivir Ther 2005; 10 Suppl 2: M3-11.

[81] Mallon PW, Unemori P, Sedwell R, et al. In vivo, nucleoside reverse-transcriptase inhibitors alter expression of both mitochondrial and lipid metabolism genes in the absence of depletion of mitochondrial DNA. J Infect Dis 2005; 191: 1686-96.

[82] Stankov MV, Schmidt RE, Behrens GM. Zidovudine impairs adipogenic differentiation through inhibition of clonal expansion. Antimicrob Agents Chemother 2008; 52: 2882-9.

[83] Saillan-Barreau C, Tabbakh O, Chavoin JP, Casteilla L, Penicaud L. Drug-specific effect of nelfinavir and stavudine on primary culture of human preadipocytes. J Acquir Immune Defic Syndr 2008; 48: 20-5.

[84] Caron M, Auclair M, Lagathu C, et al. The HIV-1 nucleoside reverse transcriptase inhibitors stavudine and zidovudine alter adipocyte functions in vitro. AIDS 2004; 18: 2127-36.

[85] Vernochet C, Azoulay S, Duval D, et al. Human immunodeficiency virus protease inhibitors accumulate into cultured human adipocytes and alter expression of adipocytokines. J Biol Chem 2005; 280: 2238-43.

[86] Jones SP, Waitt C, Sutton R, Back DJ, Pirmohamed M. Effect of atazanavir and ritonavir on the differentiation and adipokine secretion of human subcutaneous and omental preadipocytes. AIDS 2008; 22: 1293-8.

[87] Dowell P, Flexner C, Kwiterovich PO, Lane MD. Suppression of preadipocyte differentiation and promotion of adipocyte death by HIV protease inhibitors. J Biol Chem 2000; 275: 41325-32.

[88] Meininger G, Hadigan C, Laposata M, et al. Elevated concentrations of free fatty acids are associated with increased insulin response to standard glucose challenge in human immunodeficiency virus-infected subjects with fat redistribution. Metabolism 2002; 51: 260-6.

[89] Vigouroux C, Maachi M, Nguyen TH, et al. Serum adipocytokines are related to lipodystrophy and metabolic disorders in HIVinfected men under antiretroviral therapy. AIDS 2003; 17: 1503-11.

[90] Sutinen J, Hakkinen AM, Westerbacka J, et al. Increased fat accumulation in the liver in HIV-infected patients with antiretroviral therapy-associated lipodystrophy. AIDS 2002; 16: 2183-93.

[91] Moreno-Torres A, Domingo P, Pujol J, et al. Liver triglyceride content in HIV-1-infected patients on combination antiretroviral therapy studied with 1H-MR spectroscopy. Antivir Ther 2007; 12 : 195-203.

[92] van der Valk M, Gisolf EH, Reiss P, et al. Increased risk of lipodystrophy when nucleoside analogue reverse transcriptase inhibitors are included with protease inhibitors in the treatment of HIV-1 infection. AIDS 2001; 15: 847-55.

[93] Freiberg MS, Leaf DA, Goulet JL, et al. The association between the receipt of lipid lowering therapy and HIV status among veterans who met NCEP/ATP III criteria for the receipt of lipid lowering medication. J Gen Intern Med 2009; 24: 334-40.

[94] National Cholesterol Education Program. Third Report of the National Cholesterol Education Program (NCEP) expert panel on Detection, Evaluation, and Treatment of High Blood Cholesterol in Adults (Adult Treatment Panel III). 2004 [cited 2010 March 10]; Available from: http: //www.nhlbi.nih.gov/guidelines/cho-lesterol/ atp3full.pdf. 
[95] Joy T, Keogh HM, Hadigan C, et al. Dietary fat intake and relationship to serum lipid levels in HIV-infected patients with metabolic abnormalities in the HAART era. AIDS 2007; 21: 1591600 .

[96] Henry K, Melroe H, Huebesch J, Hermundson J, Simpson J. Atorvastatin and gemfibrozil for protease-inhibitor-related lipid abnormalities. Lancet 1998; 352: 1031-2.

[97] Wohl DA, Tien HC, Busby M, et al. Randomized study of the safety and efficacy of fish oil (omega-3 fatty acid) supplementation with dietary and exercise counseling for the treatment of antiretroviral therapy-associated hypertriglyceridemia. Clin Infect Dis 2005; 41: 1498-504.

[98] Manfredi R, Calza L, Chiodo F. Polyunsaturated ethyl esters of n-3 fatty acids in HIV-infected patients with moderate hypertriglyceridemia: comparison with dietary and lifestyle changes, and fibrate therapy. J Acquir Immune Defic Syndr 2004; 36: 878-80.

[99] Panel on Antiretroviral Guidelines for Adults and Adolescents. Guidelines for the use of antiretroviral agents in HIV-1-infected adults and adolescents. Department of Health and Human Services. November 3, 2008; 1-139. Available at http: //www.aidsinfo.nih. gov/ContentFiles/-AdultandAdolescentGL.pdf. Accessed 23rd December 2009.

[100] Taburet AM, Piketty C, Chazallon C, et al. Interactions between atazanavir-ritonavir and tenofovir in heavily pretreated human immunodeficiency virus-infected patients. Antimicrob Agents Chemother 2004; 48: 2091-6.

[101] Molina JM, Andrade-Villanueva J, Echevarria J, et al. Once-daily atazanavir/ritonavir versus twice-daily lopinavir/ritonavir, each in combination with tenofovir and emtricitabine, for management of antiretroviral-naive HIV-1-infected patients: 48 week efficacy and safety results of the CASTLE study. Lancet 2008; 372: 64655.

[102] Tomaka F, Lefebvre E, Sekar V, et al. Effects of ritonavir-boosted darunavir vs. ritonavir-boosted atazanavir on lipid and glucose parameters in HIV-negative, healthy volunteers. HIV Med 2009; 10: 318-27.

[103] Gatell J, Salmon-Ceron D, Lazzarin A, et al. Efficacy and safety of atazanavir-based highly active antiretroviral therapy in patients with virologic suppression switched from a stable, boosted or unboosted protease inhibitor treatment regimen: the SWAN Study (AI424-097) 48-week results. Clin Infect Dis 2007; 44: 1484-92.

[104] Soriano V, Garcia-Gasco P, Vispo E, et al. Efficacy and safety of replacing lopinavir with atazanavir in HIV-infected patients with undetectable plasma viraemia: final results of the SLOAT trial. J Antimicrob Chemother 2008; 61: 200-5.

[105] Nguyen ST, Eaton SA, Bain AM, et al. Lipid-lowering efficacy and safety after switching to atazanavir-ritonavir-based highly active antiretroviral therapy in patients with human immunodeficiency virus. Pharmacotherapy 2008; 28: 323-30.

[106] Wood R, Phanuphak P, Cahn P, et al. Long-term efficacy and safety of atazanavir with stavudine and lamivudine in patients previously treated with nelfinavir or atazanavir. J Acquir Immune Defic Syndr 2004; 36: 684-92.

[107] Sension M, Neto JL, Grinsztejn B, et al. Improvement in Lipid Profiles in Antiretroviral-Experienced HIV-Positive Patients With Hyperlipidemia After a Switch to Unboosted Atazanavir. J Acquir Immune Defic Syndr 2009; 51(2): 153-62.

[108] Estrada V, De Villar NG, Larrad MT, et al. Long-term metabolic consequences of switching from protease inhibitors to efavirenz in therapy for human immunodeficiency virus-infected patients with lipoatrophy. Clin Infect Dis 2002; 35: 69-76.

[109] Calza L, Manfredi R, Colangeli V, et al. Substitution of nevirapine or efavirenz for protease inhibitor versus lipid-lowering therapy for the management of dyslipidaemia. AIDS 2005; 19: 1051-8.

[110] Negredo E, Cruz L, Paredes R, et al. Virological, immunological, and clinical impact of switching from protease inhibitors to nevirapine or to efavirenz in patients with human immunodeficiency virus infection and long-lasting viral suppression. Clin Infect Dis 2002; 34: 504-10.

[111] Petit JM, Duong M, Masson D, et al. Serum adiponectin and metabolic parameters in HIV-1-infected patients after substitution of nevirapine for protease inhibitors. Eur J Clin Invest 2004; 34 : 569-75.

[112] Martinez E, Arnaiz JA, Podzamczer D, et al. Substitution of nevirapine, efavirenz, or abacavir for protease inhibitors in patients with human immunodeficiency virus infection. N Engl J Med 2003; 349: 1036-46.

[113] Gulick RM, Ribaudo HJ, Shikuma CM, et al. Triple-nucleoside regimens versus efavirenz-containing regimens for the initial treatment of HIV-1 infection. N Engl J Med 2004; 350: 1850-61.

[114] Moyle GJ, Sabin CA, Cartledge J, et al. A randomized comparative trial of tenofovir DF or abacavir as replacement for a thymidine analogue in persons with lipoatrophy. AIDS 2006; 20: 2043-50.

[115] Madruga JR, Cassetti I, Suleiman JM, et al. The safety and efficacy of switching stavudine to tenofovir $\mathrm{df}$ in combination with lamivudine and efavirenz in hiv-1-infected patients: three-year follow-up after switching therapy. HIV Clin Trials 2007; 8: 381-90.

[116] Llibre JM, Domingo P, Palacios R, et al. Sustained improvement of dyslipidaemia in HAART-treated patients replacing stavudine with tenofovir. AIDS 2006; 20: 1407-14.

[117] Ananworanich J, Nuesch R, Cote HC, et al. Changes in metabolic toxicity after switching from stavudine/didanosine to tenofovir/ lamivudine--a Staccato trial substudy. J Antimicrob Chemother 2008; 61: 1340-3.

[118] Martinez E, Arranz JA, Podzamczer D, et al. A simplification trial switching from nucleoside reverse transcriptase inhibitors to oncedaily fixed-dose abacavir/lamivudine or tenofovir/emtricitabine in HIV-1-infected patients with virological suppression. J Acquir Immune Defic Syndr 2009; 51: 290-7.

[119] Milinkovic A, Martinez E, Lopez S, et al. The impact of reducing stavudine dose versus switching to tenofovir on plasma lipids, body composition and mitochondrial function in HIV-infected patients. Antivir Ther 2007; 12: 407-15.

[120] Fisher M, Moyle GJ, Shahmanesh M, et al. A Randomized Comparative Trial of Continued Zidovudine/Lamivudine or Replacement With Tenofovir Disoproxil Fumarate/Emtricitabine in Efavirenz-Treated HIV-1-Infected Individuals. J Acquir Immune Defic Syndr 2009; 51: 562-8.

[121] Hatano H, Miller KD, Yoder CP, et al. Metabolic and anthropometric consequences of interruption of highly active antiretroviral therapy. AIDS 2000; 14: 1935-42.

[122] El-Sadr WM, Lundgren JD, Neaton JD, et al. CD4+ count-guided interruption of antiretroviral treatment. N Engl J Med 2006; 355 : 2283-96.

[123] Mah Ming JB, Gill MJ. Drug-induced rhabdomyolysis after concomitant use of clarithromycin, atorvastatin, and lopinavir/ ritonavir in a patient with HIV. AIDS Patient Care STDS 2003; 17: 207-10.

[124] Neuvonen PJ, Niemi M, Backman JT. Drug interactions with lipidlowering drugs: mechanisms and clinical relevance. Clin Pharmacol Ther 2006; 80: 565-81.

[125] Backman JT, Luurila H, Neuvonen M, Neuvonen PJ. Rifampin markedly decreases and gemfibrozil increases the plasma concentrations of atorvastatin and its metabolites. Clin Pharmacol Ther 2005; 78: 154-67.

[126] Gerber JG, Kitch DW, Fichtenbaum CJ, et al. Fish oil and fenofibrate for the treatment of hypertriglyceridemia in HIVinfected subjects on antiretroviral therapy: results of ACTG A5186. J Acquir Immune Defic Syndr 2008; 47: 459-66.

[127] Badiou S, Merle De Boever C, Dupuy AM, et al. Fenofibrate improves the atherogenic lipid profile and enhances LDL resistance to oxidation in HIV-positive adults. Atherosclerosis 2004; 172: 273-9.

[128] Calza L, Manfredi R, Chiodo F. Statins and fibrates for the treatment of hyperlipidaemia in HIV-infected patients receiving HAART. AIDS 2003; 17: 851-9.

[129] Palacios R, Santos J, Gonzalez M, et al. Efficacy and safety of fenofibrate for the treatment of hypertriglyceridemia associated with antiretroviral therapy. J Acquir Immune Defic Syndr 2002; 31 : 251-3.

[130] Palacios R, Santos J, Gonzalez M, et al. Efficacy and safety of atorvastatin in the treatment of hypercholesterolemia associated with antiretroviral therapy. J Acquir Immune Defic Syndr 2002; 30: 536-7.

[131] Aberg JA, Zackin RA, Brobst SW, et al. A randomized trial of the efficacy and safety of fenofibrate versus pravastatin in HIVinfected subjects with lipid abnormalities: AIDS Clinical Trials Group Study 5087. AIDS Res Hum Retroviruses 2005; 21: 757-67.

[132] Calza L, Colangeli V, Manfredi R, et al. Rosuvastatin for the treatment of hyperlipidaemia in HIV-infected patients receiving protease inhibitors: a pilot study. AIDS 2005; 19: 1103-5. 
[133] Baldini F, Di Giambenedetto S, Cingolani A, et al. Efficacy and tolerability of pravastatin for the treatment of HIV-1 protease inhibitor-associated hyperlipidaemia: a pilot study. AIDS 2000; 14: 1660-2.

[134] Mallon PW, Miller J, Kovacic JC, et al. Effect of pravastatin on body composition and markers of cardiovascular disease in HIVinfected men--a randomized, placebo-controlled study. AIDS 2006; 20: $1003-10$

[135] Fichtenbaum CJ, Gerber JG, Rosenkranz SL, et al. Pharmacokinetic interactions between protease inhibitors and statins in HIV seronegative volunteers: ACTG Study A5047. AIDS 2002; 16: $569-77$.

[136] Bonnet F, Aurillac-Lavignolle V, Breilh D, et al. Pravastatin in HIV-infected patients treated with protease inhibitors: a placebocontrolled randomized study. HIV Clin Trials 2007; 8: 53-60.

[137] Gerber JG, Rosenkranz SL, Fichtenbaum CJ, et al. Effect of efavirenz on the pharmacokinetics of simvastatin, atorvastatin, and pravastatin: results of AIDS Clinical Trials Group 5108 Study. J Acquir Immune Defic Syndr 2005; 39: 307-12.

[138] van der Lee M, Sankatsing R, Schippers E, et al. Pharmacokinetics and pharmacodynamics of combined use of lopinavir/ritonavir and rosuvastatin in HIV-infected patients. Antivir Ther 2007; 12: 1127-32.

[139] Kiser JJ, Gerber JG, Predhomme JA, et al. Drug/Drug interaction between lopinavir/ritonavir and rosuvastatin in healthy volunteers. J Acquir Immune Defic Syndr 2008; 47: 570-8.

[140] Busti AJ, Bain AM, Hall RG, 2nd, et al. Effects of atazanavir/ ritonavir or fosamprenavir/ritonavir on the pharmacokinetics of rosuvastatin. J Cardiovasc Pharmacol 2008; 51: 605-10.

[141] Wohl DA, Waters D, Simpson RJ, Jr., et al. Ezetimibe alone reduces low-density lipoprotein cholesterol in HIV-infected patients receiving combination antiretroviral therapy. Clin Infect Dis 2008; 47 : 1105-8.

[142] Negredo E, Molto J, Puig J, et al. Ezetimibe, a promising lipid-lowering agent for the treatment of dyslipidaemia in HIVinfected patients with poor response to statins. AIDS 2006; 20: 2159-64.

[143] Gerber MT, Mondy KE, Yarasheski KE, et al. Niacin in HIVinfected individuals with hyperlipidemia receiving potent antiretroviral therapy. Clin Infect Dis 2004; 39: 419-25.
[144] Dube MP, Wu JW, Aberg JA, et al. Safety and efficacy of extended-release niacin for the treatment of dyslipidaemia in patients with HIV infection: AIDS Clinical Trials Group Study A5148. Antivir Ther 2006; 11: 1081-9.

[145] World Health Organisation. Antiretroviral therapy for HIV infection in adults and adolescents. Recommendations for a public health approach. (2006 revision). Available at 2006 [cited 2010 Mar 10]; Available from: http: //www.who.int/hiv/pub/guidelines/ artadultguidelines.pdf.

[146] Mutimura E, Stewart A, Rheeder P, Crowther NJ. Metabolic function and the prevalence of lipodystrophy in a population of HIV-infected African subjects receiving highly active antiretroviral therapy. J Acquir Immune Defic Syndr 2007; 46: 451-5.

[147] Johnson LB, Saravolatz LD. Etravirine, a next-generation nonnucleoside reverse-transcriptase inhibitor. Clin Infect Dis 2009; 48: 1123-8.

[148] Steigbigel RT, Cooper DA, Kumar PN, et al. Raltegravir with optimized background therapy for resistant HIV-1 infection. N Engl J Med 2008; 359: 339-54.

[149] Gulick RM, Lalezari J, Goodrich J, et al. Maraviroc for previously treated patients with R5 HIV-1 infection. N Engl J Med 2008; 359: 1429-41.

[150] Martinez E, Garcia-Viejo MA, Blanco JL, et al. Impact of switching from human immunodeficiency virus type 1 protease inhibitors to efavirenz in successfully treated adults with lipodystrophy. Clin Infect Dis 2000; 31: 1266-73.

[151] Carr A, Hudson J, Chuah J, et al. HIV protease inhibitor substitution in patients with lipodystrophy: a randomized, controlled, open-label, multicentre study. AIDS 2001; 15: 1811 22.

[152] Martin A, Smith DE, Carr A, et al. Reversibility of lipoatrophy in HIV-infected patients 2 years after switching from a thymidine analogue to abacavir: the MITOX Extension Study. AIDS 2004; 18: 1029-36.

[153] Schewe CK, Maserati R, Wassmer G, Adam A, Weitner L. Improved lipid profiles and maintenance of virologic control in heavily pretreated HIV-infected patients who switched from stavudine to tenofovir treatment. Clin Infect Dis 2006; 42: 145-7.

[154] Miller J, Brown D, Amin J, et al. A randomized, double-blind study of gemfibrozil for the treatment of protease inhibitorassociated hypertriglyceridaemia. AIDS 2002; 16: 2195-200.

This is an open access article licensed under the terms of the Creative Commons Attribution Non-Commercial License (http://creativecommons.org/licenses/ by-nc/3.0/) which permits unrestricted, non-commercial use, distribution and reproduction in any medium, provided the work is properly cited. 